\title{
LA RESPONSABILIDAD PENAL DE LA PERSONA JURÍDICA TRAS LA REFORMA DE LA LO 5/2010: ENTRE LA HÉTERO Y LA AUTORRESPONSABILIDAD*
}

\author{
Criminal liability of moral persons after the reform of the LO 5/2010: \\ Among the hetero-and self-reliance
}

Prf. Dr. Alfonso Galán Muñoz**

Resumen: En el presente artículo se analizan los múltiples problemas y retos que afronta el nuevo sistema de responsabilidad penal de las personas jurídicas introducido por la LO $5 / 2010$, para buscar una interpretación que lo dote de un fundamento seguro y permita además responder a las exigencias político-criminales que dichos entes plantean al moderno Derecho penal, sin sacrificar en el empeño las garantías que ha de observar cualquier sistema de imputación de responsabilidad penal de un verdadero Estado democrático y de Derecho.

Palabras clave: persona jurídica - responsabilidad penal - política criminal - programas de cumplimiento - criminalidad de la empresa - moderno derecho penal.

\begin{abstract}
In this paper are analyzed the multiple problems and challenges arose by the introduction of the new criminal liability system for legal persons, created by the LO $5 / 2010$, with the intention of looking for an interpretation, which gives a safe ground to the system and also allows to respond to the necessities of criminal policy that those entities pose to the modern criminal law, without sacrificing in the attempt the guaranties that must be respected by any system of imputation of a true democratic State.
\end{abstract}

Keywords: legal person - criminal liability - criminal policy - compliance programs economic crimes - modern criminal law.

\section{Introducción}

Si ha habido un tema objeto de controversia en los últimos tiempos en el seno de la doctrina española, éste ha sido el referido al reconocimiento de la posibilidad de imputar responsabilidad penal a las personas jurídicas. Pocas cuestiones han suscitado tantas y tan enfrentadas opiniones como ésta, encontrándonos con algunas que se manifiestan radicalmente en contra de dicho reconocimiento y otras que, sin embargo, entienden que su implantación no sólo sería conveniente, sino

\footnotetext{
* El presente trabajo es una versión ampliada y corregida de las conferencias impartidas en las Universidades de Las Palmas de Gran Canaria y La Laguna los días 18 y 19 de noviembre de 2010 respectivamente.

** Profesor Titular de Derecho penal, Universidad Pablo de Olavide.

Correo electrónico: agalmun@upo.es.
} 
Galán - La responsabilidad penal de la persona jurídica...

que resulta absolutamente imprescindible y prácticamente inevitable en una sociedad postindustrial como la actual.

Quienes defendían el tradicional principio penal recogido en el aforismo Societas delinquere non potest sostenían que el reconocimiento de la responsabilidad penal de entes colectivos chocaba frontalmente con la ausencia en ellos de algunas de las capacidades que dotarían de contenido a las categorías básicas configuradoras de la teoría general del delito como sistema de imputación de la responsabilidad jurídico-penal.

Así, se afirmaba que al no ser las personas jurídicas entes autoconscientes dotados de capacidad de formar una verdadera y autónoma voluntad, no podían realizar conductas propias que pudiesen dar lugar a la apreciación de las acciones u omisiones que se requieren para iniciar el camino que llevaría a la imputación de responsabilidad penal conforme a la citada teoría, con lo que su carencia de capacidad de acción impediría que se les pudiesen atribuir los injustos típicos de los delitos de los que se les tratasen de responsabilizar. ${ }^{1}$

En esta misma línea, se afirma que si las personas jurídicas realizan contratos e intervienen en el tráfico jurídico es gracias a las decisiones y actuaciones de algunas personas físicas (sus representantes, administradores, etc.), con lo que lo lógico será pensar que deben ser estos últimos y no aquéllas, quienes tendrían que recibir cualquier responsabilidad penal que se pudiese derivar de la realización de tales actividades cuando llegasen a ser delictivas.

Imputar a la persona jurídica responsabilidad por algo que habría hecho de forma completamente autónoma un ser autoconsciente diferente supondría hacerle responsable de un hecho ajeno. De un hecho que en realidad habría cometido un tercero, lo que llevaría a que dicha imputación violase una de las exigencias básicas derivadas del irrenunciable principio penal de culpabilidad, como es la exigencia de la personalidad de las penas. ${ }^{2}$

Pero la posibilidad de imputar responsabilidad penal a las personas jurídicas no sólo se enfrenta a estos problemas. El hecho de que se las considerase como entes carentes de voluntad propia también lleva a que se niegue que gocen de verdadera capacidad de culpabilidad.

Las normas penales tratan de motivar a los ciudadanos para que realicen o no realicen determinados comportamientos, siendo precisamente el hecho de que

\footnotetext{
1 Así, por ejemplo, Gracia Martín, L. "La cuestión de la responsabilidad penal de las propias personas jurídicas" en Dogmática penal, politica criminal y criminología en evolución. Ed. Comares. Universidad de La Laguna, 1997, pp. 107 y ss.

2 Mir Puig, S. Derecho Penal. Parte General. Ed. Reppertor. Barcelona, 2005, p. 194; el mismo autor en "Una tercera vía en materia de responsabilidad penal de las personas jurídicas, en RECPC 06-01 (2004), en http://criminet.ugr.es/recpc/06/recpc06-01.pdf (últ. vis. 12-7-2011), pp. 01-9.
} 
decidan no cumplir con lo que las normas les exigen, pese a haber podido ser motivados de una forma suficiente por ellas, lo que permite considerarles culpables del injusto que habrían realizado al incumplirlas. ${ }^{3}$

Sin embargo, las personas jurídicas no se pueden motivar por las normas que se les dirijan, con lo que, incluso si se les llegase a poder imputar algún injusto, resultaría imposible considerarlas culpables del mismo al carecer de capacidad de culpabilidad que se necesitaría para poder hacerlo. ${ }^{4}$

Pese a todo, tampoco ha sido éste el último argumento técnico sustentado contra el reconocimiento de su responsabilidad penal. También se ha afirmado que el hecho de que estas entidades supongan meras ficciones jurídicas que permiten imputar derechos y obligaciones a un conjunto de activos patrimoniales unificados y dotados de personalidad jurídica, impediría que las penas que se les pudiesen llegar a imponer lograsen alcanzar los efectos preventivos que tienen que cumplir, incluso por exigencia constitucional.

Así, por ejemplo, ¿cómo se intimidaría a una persona jurídica si no se la puede motivar? Y lo que es incluso más importante, ¿cómo se la reeducaría? ¿Cómo se articularía su proceso de reinserción social expresamente exigido por nuestra Constitución española para todas las penas?

La persona jurídica mostraría así una nueva incapacidad. Carecería de capacidad de punibilidad y con ello se volvería a demostrar la vigencia del viejo principio de que las Sociedades, como tales, no solo no pueden delinquir, sino que además tampoco pueden ser penadas. ${ }^{5}$

Frente a esta postura se alzaban, sin embargo, las voces de quienes afirmaban que el Derecho penal no podía permanecer ajeno a la importancia que estas entidades tienen en la sociedad actual.

Las personas jurídicas constituyen, al día de hoy, el grupo más nutrido, importante y poderoso de los actores económicos. La cada vez mayor exigencia de acumulación de capitales y recursos para realizar actividades económicas lleva necesariamente a que éstos se agrupen a través de la constitución de numerosas y cada vez más grandes y complejas entidades colectivas.

\footnotetext{
3 Sobre este concepto de culpabilidad y sus consecuencias véase lo señalado por Muñoz Conde, F. / García Arán, M. Derecho Penal. Parte General. Ed. Tirant lo Blanch, Valencia, 2010, pp. 352 y ss.

${ }^{4}$ Así, entre otros, López Peregrín, C. "La discusión sobre la responsabilidad penal de las personas jurídicas y las consecuencias accesorias del art. 129 CP, once años después" en Problemas actuales del Derecho penal y de la criminología. Estudios penales en memoria de la profesora Dra. María del Mar Diaz Pita. Ed. Tirant lo Blanch. Valencia, 2008, p. 568.

5 García Arán, M. "Algunas Consideraciones sobre la responsabilidad penal de las personas jurídicas”, en El nuevo Código Penal: presupuestos y fundamentos, libro homenaje al profesor Doctor Don Ángel Torio López. Ed. Comares. Granada, 1999, p. 326.
} 
Galán - La responsabilidad penal de la persona jurídica...

Actividades tales como la energética, la financiera, la química o la farmacéutica, entre otras muchas, serían difícilmente realizables en el mundo actual de no mediar la utilización de este tipo de entidades, hecho que las convierte en agentes esenciales de la economía no sólo nacional sino mundial, pero también les otorga el papel de titulares y responsables de muchos de los más importantes focos de grandes riesgos de las sociedades postindustriales. ${ }^{6}$

Parece innegable que riesgos como los medioambientales, los relativos a la salud pública, los referidos a la energía atómica o incluso la mayoría de los que pueden llegar a poner en jaque a grandes e importantes sectores del sistema económico actual (sistema financiero, bolsa, etc.) proceden de actividades realizadas por personas jurídicas, circunstancia que llevó hace ya algún tiempo a Schünemann a afirmar que el Derecho penal estaba obligado a dar una respuesta preventiva adecuada a su existencia e importancia, dejando a un lado los posibles problemas técnico-dogmáticos que la implantación de dicha respuesta le pudiese plantear, ya que existiría un verdadero estado de necesidad político-criminal que justificaría tal sacrificio. ${ }^{7}$

A su juicio, el Derecho penal no podía permanecer de espaldas a una realidad como la de la existencia de las personas jurídicas que podía llegar a actuar como factor criminógeno de primer orden, ya que, por una parte, podría servir para establecer verdaderas estructuras organizadas de irresponsabilidad penal individual, donde la distribución y dispersión de las funciones y toma de decisiones

\footnotetext{
${ }^{6}$ En este sentido, señala Heine, G. que la aparición de los nuevos y enormes riesgos propios de estas sociedades, unida al hecho de que el Estado haya ido perdiendo el monopolio sobre la protección de bienes jurídicos, la distribución de riesgos y la planificación de estrategias, por carecer de los conocimientos y las competencias necesarias para ejercerlos, obliga a incrementar la autorresponsabilidad de las empresas que son las únicas entidades dotadas de los conocimientos y de las competencias necesarias para poder controlarlos. En "Modelos de responsabilidad jurídicopenal originaria de la empresa", en Modelos de autorresponsabilidad penal empresarial. Propuestas globales contemporáneas. Ed. Aranzadi. Cizur Menor (Navarra), 2006, pp. 30 y ss. En similares términos se manifiesta también, Nieto Martín, A. La responsabilidad penal de las personas jurídicas: Un modelo lesgislativo. Ed. Iustel. Madrid, 2008, pp. 64 y ss; Zúñiga Rodríguez, L. Bases para un modelo de imputación de responsabilidad penal a las personas jurídicas. Ed. Aranzadi. Cizur Meno (Navarra), 2009, pp. 77 y ss. y 113 y ss.

${ }^{7}$ En concreto, Schünemann, B. señala que el debilitamiento de la eficacia preventiva del Derecho penal en el ámbito de la criminalidad de la empresa da lugar a un estado de necesidad de protección del bien jurídico (Rechtsgüternotstand) que legitimaría dicho sacrificio. En Unternehmenskriminalität und Strafrecht-Eine Untersuchung der Verantwortlichkeit der Unternebmen und ibre Führungskeäfte nach geldentem und replanten Straf- und Ordnungswiedrigkeitenrecht, Ed. Heymnann. Köln, 1979, p. 236, manteniendo su postura en múltiples trabajos posteriores, como por ejemplo, "La punibilidad de las personas jurídicas desde la perspectiva europea" en Hacia un Derecho penal económico europeo- Ed. BOE. Madrid, 1995, pp. 589 y ss. o, más recientemente en "Responsabilidad penal en el marco de la empresa. Dificultades relativas a la individualización de la imputación" en ADPCP, Vol. LV, 2002, p. 22 y en "La responsabilidad penal de las empresas y sus órganos directivos en la Unión europea" en Constitución europea y Derecho penal económico. Mesas redondas Derecho y economía. Ed. Ramón Areces. Madrid, 2006, p. 151.
} 
entre las personas físicas integradas en su organización harían que nunca se pudiese llegar a encontrar a uno en el que se diesen todos los elementos objetivos y subjetivos que permitirían considerarle responsable penal del daño producido por la empresa; ${ }^{8}$ mientras que, por otra, también podría ser utilizada como paraguas impermeabilizador frente a la motivación de las normas penales que servirían para neutralizar la capacidad de influencia que éstas tratan de ejercer sobre tales individuos, gracias a la implantación de una cultura empresarial que, directa o indirectamente, les alentaría a cometer delitos o actividades arriesgadas y peligrosas, premiando incluso su realización por considerarlas como muestras del espíritu emprendedor y atrevido que se requiere para conquistar el éxito económico. ${ }^{9}$

Sólo hace falta ver los últimos acontecimientos económicos producidos en Estados Unidos y en el resto del mundo como consecuencia de la cultura empresarial de la especulación, para ver hasta qué punto eran correctas y premonitorias las palabras del citado profesor, siendo la dimensión mundial de estos acontecimientos, por otra parte, la que nos pone sobre la pista de otro de los argumentos que parecen respaldar la necesidad político-criminal del reconocimiento de la responsabilidad penal de las personas jurídicas, ya que si hay una característica que defina a este tipo de entidades en la economía actual es la que nos viene dada por el hecho de que superan con enorme facilidad las fronteras nacionales gracias a su fácil deslocalización. ${ }^{10}$

En efecto, una persona jurídica puede tener su sede central en Europa, su producción en Asia y realizar la comercialización de sus productos en América, sin que nada le impida cambiar dichas localizaciones con asombrosa rapidez atendiendo a sus propios intereses y necesidades.

Las empresas no conocen de fronteras nacionales, pero las normas penales sí y es por ello por lo que la existencia de diferentes posicionamientos nacionales respecto al cuestionado tema de su posible responsabilidad penal de las personas jurídicas puede llevar a que éstas opten por implantarse en aquellos países que tengan un régimen más benévolo o "tolerante" ante sus actuaciones más peligrosas o cuestionables, provocando de este modo un efecto de llamada de estos países menos severos en el tratamiento de la responsabilidad penal de las empresas, que podría dar lugar a un verdadero efecto "Delaware" que llevase a que los Estados con menos escrúpulos utilizasen el no reconocimiento de su responsabilidad penal

\footnotetext{
${ }^{8}$ Schünemann, B. "La punibilidad de las personas jurídicas (...)”, p. 573.

${ }^{9}$ Schünemann, B. "La punibilidad de las personas jurídicas (...)”, p. 580.

10 Sobre este fenómeno, véase Beck, U. ¿Qué es la globalización?. Ed. Paidos. Barcelona, 2008, pp. 21

y ss. y sobre los problemas de todo tipo que el mismo plantea a la concepción tradicional del ius puniendi estatal, lo apuntado por Nieto Martín, A. op. cit. ant., pp. 56 y ss.

11 Vogel, J. "Estado y tendencias de la armonización del Derecho penal material en la Unión europea". RP No 10, 2002, p. 116.
} 
Galán - La responsabilidad penal de la persona jurídica...

precisamente como instrumento jurídico que les permitiría practicar una suerte de "competencia desleal" con respecto a aquellos otros que sí lo hiciesen.

La necesidad de erradicar posibles paraísos para la criminalidad de las empresas en un mercado globalizado es por sí misma un argumento de peso para afrontar una armonización mundial en esta materia, pero cobra aún mayor valor cuando se pone en relación con una realidad como la de la Unión Europea, donde la existencia de un mercado único hace que el hecho de que algunos de sus Estados miembros reconozcan dicha responsabilidad mientras que otros sigan sin hacerlo suponga una cuestión de primer orden que tiene que ser resuelta con urgencia.

No debe sorprender, por tanto, que haya sido desde instancias comunitarias, desde donde más insistentemente se ha pedido a España que reconozca y habilite un sistema para reconocer la responsabilidad penal de las personas jurídicas, ni que la Ley Orgánica 5/2010, que ha venido a modificar el actual Código Penal en esta materia, aluda expresamente a las demandas internacionales de incriminación de dichas entidades, y especialmente a las comunitarias, como a uno de los referentes básicos de la reforma realizada. ${ }^{12}$

Como acabamos de ver, parece que en este tema se produce un claro enfrentamiento entre las exigencias político-criminales de la sociedad actual y los rígidos criterios delimitadores de la tradicional teoría general del delito que se ha ido desarrollando como sistema de imputación de responsabilidad penal específicamente dirigido hacia las personas físicas.

Nadie discute el hecho de que la teoría general del delito actual no se ajusta a los parámetros que definen y caracterizan a las personas jurídicas. Es una teoría desarrollada atendiendo a las características y peculiaridades de la persona física, con lo que no puede responder a las que definen a las jurídicas como entes colectivos diferentes de aquéllos; hecho que ha llevado a que la mayor parte de quienes propugnan la necesidad de atribuirles una verdadera responsabilidad penal a proponer que se cree un nuevo sistema de imputación, distinto del aplicable a las personas físicas y que atienda específicamente a las características y peculiaridades propias de estos nuevos sujetos activos del Derecho penal, para que se les pueda imputar dicha clase de responsabilidad sin sacrificar en el intento los principios y garantías que la caracterizan e incluso la diferencian de otras que ya se le atribuyen sin mayores dificultades. Veamos algunas de las propuestas realizadas en esta línea.

\footnotetext{
12 Así, se dice expresamente en el preámbulo de la citada Ley Orgánica “...Se regula de manera pormenorizada la responsabilidad penal de las personas juridicas. Son numerosos los instrumentos jurídicos internacionales que demandan una respuesta penal clara para las personas jurídicas, sobre todo en aquellas figuras delictivas donde la posible intervención de las mismas se hace más evidente (...)”.
} 
REJ - Revista de Estudios de la Justicia - No 15 - Año 2011

\section{Posibles sistemas de imputación de responsabilidad penal a las personas jurídicas}

Como se comprenderá, resulta absolutamente imposible analizar en este trabajo las peculiaridades que presentan todos y cada uno de los sistemas de imputación de responsabilidad penal a las personas jurídicas que se han propuesto o se han llegado a crear en los países nuestro entorno jurídico más cercano.

Sin embargo, creemos que todos ellos podrían ser agrupados, grosso modo, en dos grandes grupos.

Por una parte estarían los sistemas de heterorresponsabilidad; mientras que, por otra, estarían los denominados sistemas de autorresponsabilidad. ${ }^{13}$

El primer grupo de sistemas, los de heterorresponsabilidad, parten de la comisión de un hecho delictivo realizado por una persona física, considerando que dicho hecho será imputable o atribuible a una persona jurídica cuando se den determinados requisitos de carácter formal o material.

Así, por ejemplo, nos encontramos con que se propone atribuir responsabilidad penal a la persona jurídica por los hechos delictivos que hubiesen cometido quienes actuasen en su nombre o representación (criterio formal de atribución) o por aquellos que realizasen quienes, pese a no ostentar su representación legal, si ostentasen y ejerciesen competencias de decisión o de control sobre su actividad (criterio material de atribución).

Se afirmaría entonces que las personas jurídicas responderían por los delitos que cometiesen las personas físicas que fuesen, de una u otra forma, quienes decidiesen su actuación en el mercado. Es decir, responderían por los delitos que cometerían quienes actuasen como su alter ego físico frente a terceros, sistema que se ajusta perfectamente a lo sostenido por otras ramas del ordenamiento jurídico, pero que plantearía serios problemas al Derecho penal.

Así, por ejemplo, parece evidente que estos sistemas se enfrentarían a graves problemas a la hora de responder a las exigencias derivadas del principio de culpabilidad, ya que, no sólo parecen establecer un sistema de responsabilidad objetiva para dichas entidades, sino que además resulta evidente que, al fin y al cabo, las harían responder por un hecho que habría cometido un tercero y no por uno propio, lo que contrariaría de forma flagrante la exigencia penal de responsabilidad personal. ${ }^{14}$

\footnotetext{
13 Mantenemos, por tanto, la clasificación que en su día realizó Gómez-Jara Díez, C. en "Autoorganización empresarial y autorresponsabilidad empresarial" en RECPC 08-05 (2006), en http://criminet.ugr.es/recpc/08/recpc08-05.pdf (últ. vis. 2-7-2011), p. 05:21.

14 Bajo Fernández, M. / Bacigalupo Saggese, S. Derecho penal económico. Ed. Ramón Areces. Madrid, 2010, p. 171, Martínez-Buján Pérez, C. Derecho penal económico. Parte General. Ed. Tirant Lo
} 
Galán - La responsabilidad penal de la persona jurídica...

Tampoco parece que los criterios delimitadores de la atribución de responsabilidad a la persona jurídica característica de estos sistemas resulten del todo convincentes y seguros. ¿Por qué limitar la responsabilidad de la persona jurídica a los delitos cometidos por sus representantes o por quienes las administran de hecho? Es decir, ¿por qué limitar el círculo de personas que pueden generar la responsabilidad de dichos entes a los representantes o a sus administradores de hecho o de derecho? ¿Es que acaso no hay otras personas integradas en el seno de dichas entidades que sin tener dichas cualidades podrían cometer delitos al amparo o incluso auspiciados por la cultura empresarial reinante en ellas?

En esta misma línea, también se ha señalado que la implantación de este tipo de sistemas resultaría completamente ineficaz, al tener una escasa o incluso una nula eficacia preventiva.

Muchos son los reproches en este aspecto.

No es sólo que estas propuestas no afronten el fenómeno de la criminalidad de empresa teniendo en cuenta la enorme complejidad organizativa que presentan muchas de estas entidades al olvidarse de los escalones intermedios e inferiores de sus organizaciones, ${ }^{15}$ sino también que al partir de una atribución de responsabilidad penal a las personas jurídicas por los delitos cometidos por un circulo más o menos amplio de personas físicas sin establecer mayores exigencias, parecerían estar transmitiendo un mensaje hacia tales entidades que podría llevar a pensar a quienes la integran que hagan lo que hagan siempre tendrán que responder por los posibles desvaríos que cometan sus representantes o directivos, lo que privará a la amenaza de su posible sanción penal de cualquier clase de efecto

Blanch. Valencia, 1999, p. 239; Gómez Tomillo, M. Introducción a la responsabilidad penal de las personas jurídicas en el sistema español. Ed. Lex Nova. 2010, p. 101; Gómez-Jara Díez, C. "El modelo constructivista de autorresponsabilidad penal empresarial", en Modelos de autorresponsabilidad penal empresarial. Propuestas globales contemporáneas. Ed. Aranzadi. Cizur Menor (Navarra), 2006, p. 116 o Feijoo Sánchez, B. "La responsabilidad penal de las personas jurídicas", en Estudios sobre las reformas del Código penal operadas por las LO 5/2010de 22 de junio y 3/2011 de 28 de enero. Ed. Civitas. Cizur Menor (Navarra), 2011, ant. cit., p. 81, entre otros.

15 Así, por ejemplo, Nieto Martín, A. reprocha a algunos de estos sistemas que solo permitan atribuir responsabilidad a la persona jurídica por las actuaciones de sus órganos directivos superiores, es decir, aquellos que tienen una capacidad de decisión autónoma y no sometida a supervisión, lo que determinará que las conductas delictivas de los cargos intermedios, realizadas incluso por expresa delegación de sus superiores, no puedan nunca llegar a reportar responsabilidad penal a la persona jurídica, mientras estos últimos sujetos se reserven alguna capacidad de supervisión respecto a su actuación. En op. cit. ant. p. 92. Precisamente, este problema es el que nos lleva a no compartir el concepto estricto de administrador defendido respecto al sistema español por Feijoo Sánchez, B., conforme al cual no se podría considerar por tal a los cargos intermedios que estuviesen sometidos al control o a la autoridad de otros superiores, por muy grande e importante que fuese su nivel y capacidad de decisión. En "La responsabilidad penal de las personas jurídicas...” ant. cit., p. 97. 
preventivo que las motive para establecer medidas controladoras y neutralizadoras de sus posibles actuaciones delictivas.

Pese a la importancia de las críticas anteriores tal vez el mayor reproche político-criminal que se haya dirigido a estas propuestas sea aquel que señala que las mismas no responderán a una de las principales exigencias preventivas que se han utilizado como argumento en favor del establecimiento de los sistemas de responsabilidad penal para las personas jurídicas, por cuanto, al ser sistemas que exigen, siempre y necesariamente, que se impute la comisión de un delito a una persona física para poder atribuir responsabilidad penal a la jurídica, no permitirán que el Derecho penal pueda responder de forma adecuada a los supuestos en que ésta se haya organizado como una verdadera estructura de irresponsabilidad penal individual, donde la responsabilidad de la persona física quede completamente difuminada o resulte imposible de concretar. ${ }^{16}$

Así, por ejemplo, nos encontraríamos con que el Derecho penal de la persona jurídica creado conforme a estos sistemas continuaría dejando sin sanción los casos de management defectuoso, en los que el daño generado no procediese de la conducta dolosa o imprudente de una única persona física inserta en la estructura empresarial, sino de sucesivas y no concertadas actuaciones $y / u$ omisiones de varios sujetos diferentes que habrían realizado conductas inocuas o permitidas desde un punto de vista individual, pero que, al haberse realizado de forma acumulada en el seno de su estructura, habrían provocado la afección lesiva que el Derecho penal debería tratar de impedir.

Pero es que además, y en el mismo sentido, este tipo de sistemas tampoco brindaría una adecuada respuesta penal al problema que plantean aquellos otros supuestos en los que habiéndose constatado la comisión de una conducta individual penalmente relevante por parte de una o varias de las que actuaban en el seno de la empresa, no se pudiese concretar o determinar quién o quiénes habrían sido éstas, como sucedería, por ejemplo, cuando el efecto lesivo que el Derecho penal quería evitar se hubiese producido como consecuencia de un acuerdo adoptado en una votación secreta y no unánime realizada en el seno de un órgano colegiado; caso en el que el sistema de responsabilidad penal individual mostraría su absoluta inutilidad a la hora de enfrentarse a las actuaciones de entes colectivos, ya que nunca permitiría que se pudiese imputar responsabilidad a ninguno de los intervinientes en dicha decisión, al no poder saberse con certeza y más allá de toda

\footnotetext{
16 Así, por ejemplo, Silva Sánchez, J. M. reprocha a estos sistemas el que no solucionen precisamente los problemas preventivos que plantea el sistema de responsabilidad individual y que justificaban la necesidad político-criminal de la creación de uno colectivo. En "La responsabilidad penal de la persona jurídica y las consecuencias accesorias del art. 129 del Código penal” En Derecho penal económico. Manuales de formación continuada, 14. Madrid, 2001, pp. 324 y ss. En el mismo sentido, Gómez-Jara Díez, C. en "El nuevo artículo 31.2 del Código penal: cuestiones de lege lata y de lege ferenda", en Modelos de autorresponsabilidad penal empresarial. Propuestas globales contemporáneas. Ed. Aranzadi. Cizur Menor (Navarra), 2006, p. 293.
} 
Galán - La responsabilidad penal de la persona jurídica...

duda razonable quiénes votaron a favor del acuerdo y quiénes, sin embargo, lo hicieron en contra. ${ }^{17}$

Todos estos problemas llevaron a parte de la doctrina a buscar nuevos caminos a la hora de crear un sistema de imputación penal de las personas jurídicas. El punto de partida común a todos estas propuestas vendría dado por el hecho de que todas ellas tratarían de buscar un sistema que permitiese fundamentar la responsabilidad penal de la persona jurídica en su propia actuación y no en la de una persona física que tuviese algún tipo de relación con la misma, dando lugar a la aparición de los denominados sistemas de autorresponsabilidad.

Pese a las diferencias existentes entre los distintos sistemas de autorresponsabilidad propuestos, todos ellos parecen asentarse, en mayor o en menor medida, en el hecho de que la persona jurídica podrá y tendrá que responder cuando se constate que fue su defectuosa organización y/o funcionamiento, la que permitió o favoreció la comisión del delito cometido por una o varias de las personas físicas que actuaban en su seno.

El origen de estas teorías se encuentra en los trabajos inicialmente realizados por el profesor Tiedemann, quien trató de sustentar la imputación de responsabilidad de las empresas previstas en la Ley de contravenciones alemana en la propia culpabilidad que dichas entidades tendrían por su propia organización; ${ }^{18}$ propuesta que posteriormente ha sido desarrollada, matizada e incluso criticada en algunos aspectos por otros autores de la doctrina alemana (como Heine, ${ }^{19}$ entre otros) y española (como Gómez-Jara Díez ${ }^{20}$ o Nieto Martín $)^{21}$ que han tratado de perfeccionarla para que respondiese de la mejor forma posible a las exigencias preventivas que plantea la existencia e importancia de este tipo de entidades en una realidad social como la actual.

\footnotetext{
17 Compartimos, por tanto, la postura sostenida por Núñez Castaño, E. cuando señala que en el caso de votaciones secretas adoptadas por mayoría "...no se sabe cuáles son las manifestaciones de voluntad individuales que conforman la voluntad común", con lo que "...será imposible determinar la imputación objetiva individual, sobre la base de lo que cada administrador, en concreto, realizó. Por consiguiente el delito queda impune”. En Responsabilidad penal en la empresa. Ed. Tirant lo Blanch. Valencia, 2000, p. 160. En contra de esta postura se manifiestan, sin embargo, Bajo Fernández, M. / Bacigalupo Saggese, S. quienes consideran que la existencia de un deber de garante en todos los miembros del órgano determinaría que se les pudiese imputar a todos la decisión adoptada, por más que se hubiese tomado mediante una votación secreta. En op. cit. ant., p. 138.

18 Tiedemann, K. "Die "Bebussung” von Unternehmen nach dem z. Gesetz zur Bekämpfung der Wirtschaftskriminalität”, NJW Heft 19, 1998, p. 1173.

19 Heine, G. Die strafrechtliche Verantwortlichkeit von Unternebemen, Von individuallen Feblverbalten zu kollektiven Feblenwircklungen inbesodnere bei Grossrisiken. Ed. NOMOS. Baden Baden, 1995.

${ }^{20}$ Gómez-Jara Díez, C. La culpabilidad penal de la empresa. Ed. Marcial Pons. Madrid, 2005.

${ }^{21}$ Nieto Martín, A. La responsabilidad penal de las personas jurídicas: Un modelo lesgislativo. Ed. Iustel. Madrid, 2008.
} 
Pese todo, tampoco parece que los desarrollos realizados por todos los defensores de las teorías de la autorresponsabilidad hayan conseguido solucionar los problemas a los que se enfrenta el reconocimiento y establecimiento de un verdadero sistema de responsabilidad penal para las personas jurídicas.

Así, y en primer lugar, este tipo de sistemas plantea graves problemas a la hora de concretar cuándo se producirán los defectos organizativos que pueden generar la responsabilidad penal de tales entidades. ¿Cuándo se dará realmente uno de los defectos organizativos que pueden generar la responsabilidad penal de los entes corporativos? ¿Cuándo dicho defecto es lo suficientemente grave como para determinar su responsabilidad? ¿Es indiferente dónde se dé el defecto? ¿Cualquier defecto será suficiente para hacer automáticamente responsable a la persona jurídica de los delitos que cometan personas físicas en su seno? Es más, ¿¿se podría suponer que siempre que se dé un delito en el seno de una empresa se deberá a que ésta no se había organizado correctamente? ${ }^{22}$

En definitiva, ¿cómo se determina el nivel de vigilancia que la persona jurídica ha de respetar al organizarse para quedar exenta de cualquier posible imputación de responsabilidad penal por los delitos que las personas físicas puedan cometer en su seno? ¿Dónde está la frontera del riesgo organizativo permitido que dichas entidades no deben traspasar? ${ }^{23}$

La pregunta, como se comprenderá, está lejos de ser intrascendente y hasta el momento sólo ha encontrado una respuesta dotada de una cierta seguridad jurídica por parte de aquellos autores que, importando a nuestro sistema parámetros de imputación de responsabilidad penal propios del ámbito anglosajón, consideran que tales defectos existirán cuando la persona jurídica en cuestión no tenga implantados programas de cumplimientos normativos (Compliance program) que traten de implantar una cultura empresarial de respeto al Derecho en su organización ni establezca sistemas de control y prevención adecuados, tendentes a evitar la realización de delitos en su seno $;^{24}$ planteamiento que, sin embargo, ha sido criticado por otro importante sector doctrinal que considera que tales

\footnotetext{
22 Así lo hace, por ejemplo, Gómez Tomillo, M. quien considera que una vez constatada la tipicidad y antijuridicidad de la acción u omisión imputable a la persona jurídica, su culpabilidad basada en un defecto organizativo interno se podrá afirmar y presumir de una forma iuris tantum, lo que obligará a la persona jurídica a demostrar que se dotó de una organización preventiva eficiente, si es que quiere quedar exenta de cualquier sanción penal por el hecho antijurídico que se le fuese a atribuir. En op. cit. ant., pp. 131 y ss.

${ }^{23}$ Este problema es destacado por Gómez-Jara Díez, C. quien señala que tendrán que ser la dogmática y la jurisprudencia las que tendrán que definir cuáles habrían de ser los deberes de supervisión que se habrían de respetar. En "La responsabilidad penal de las personas jurídicas en la reforma del Código penal”. La Ley No 7534, 2010, en www.laley.es (últ. vis. 1-5-2011).

24 Así, entre otros, Gómez-Jara Díez, C. "La responsabilidad penal de las personas jurídicas en la reforma..." cit. ant. o Alonso Gallo, J. "Los programas de cumplimiento", en Estudios sobre las reformas del Código penal operadas por las LO 5/2010de 22 de junio y 3/2011 de 28 de enero. Ed. Civitas. Cizur Menor (Navarra), 2011, pp. 147 y ss.
} 
Galán - La responsabilidad penal de la persona jurídica...

programas son meros parapetos que tratan de vender una imagen maquillada de la empresa como ente comprometido con la prevención de delitos, sin ser en modo alguno eficaces a la hora de evitar que tales entidades se utilicen o incluso incentiven su comisión, como lo demuestra el hecho de que muchos de los mayores casos de delincuencia empresarial producido en los últimos años en los Estados Unidos se hayan dado, precisamente, en empresas que alentaron y fomentaron la comisión de delitos por parte de sus directivos, pese a tener férreos programas de cumplimiento que supuestamente tendían a evitarlos (p. ej. Enron). ${ }^{25}$

Por otra parte, los sistemas analizados también tienen serias dificultades a la hora de justificar por qué razón la pena de la persona jurídica no se impone atendiendo sólo a la existencia de dicho defecto y a la gravedad del mismo, sino que va a depender, siempre y en todo caso, de que una persona física cometa un delito en su seno y va a tener además una gravedad acorde a la del delito que esta última cometa.

Los sistemas de autorresponsibilidad no consiguen fundamentar y establecer el nexo de conexión que debería existir entre el defecto organizativo de la persona jurídica y la conducta delictiva efectuada por la persona física que va a dar lugar a su responsabilidad, ${ }^{26}$ entendiendo algunos autores, como Tiedemann que dicha conexión se habría de sustentar acudiendo a la teoría de la actio libera in causa, ya que la conducta defectuosa empresarial se habría producido con antelación al hecho delictivo individual en el que vino a concretarse, ${ }^{27}$ mientras que otros, como Heine, afirman que lo que en estos casos se produce es una defectuosa conducción de la actividad empresarial prolongada en el tiempo que

\footnotetext{
25 Véase en este sentido lo comentado respecto a este caso por Carbonell Mateu, J. C. /Morales Prats, F. en "Responsabilidad penal de las personas jurídicas", en Comentarios a la reforma penal de 2010, Tirant lo Blanch. Valencia, 2010, pp. 67 y ss. En línea con lo anterior, señala Schunemann, B. que existe un notable desencanto en los Estados Unidos respecto a los programas de cumplimiento de normas, por cuanto se ha constatado que los mismos en muchas ocasiones sólo sirven de máscara externa que no logra cambio alguno en la verdadera cultura empresarial sostenida por la persona jurídica, ya que "...Los mejores programas Compliance no poseen valor cuando el management intermedio es obligado con un guiño de ojo de los órganos de dirección para que cometa delitos en interés o ganancia empresarial" En "La responsabilidad penal de las empresas...”, p. 154. En este mismo sentido, señala Nieto Martín, A. que el caso Enron ha sido el detonante de toda una serie de críticas referidas a este sistema, ya que se la tenía como empresa modelo en lo que se refiere a la implantación de programas de cumplimiento y prevención, lo que llevó a que se tildase de mera cosmética a estos programas que parecían actuar como un mero seguro frente al riesgo de imputación penal y a que se destacase el hecho de que además habían dado lugar a todo un deslizamiento de la imputación penal hacia las personas físicas integradas en los escalones inferiores de la entidad que estarían dispuestos a asumir la responsabilidad del hecho cometido, de forma incluso voluntaria y restribuidad, con lo que se convertirían en verdaderos chivos expiatorios que eximirían a la entidad. En op. cit. ant., pp. 207 y ss.

${ }^{26} \mathrm{La}$ ausencia de nexo jurídico entre la actuación empresarial y el delito cometido por el individuo es criticado, entre otros, por Robles Planas, R. en “¿Delitos de personas jurídicas?”. En Indret, 344, en http://www.indret.com/pdf/344.pdf (últ. vis. 12-3-2011), pp. 15 y 19.

${ }^{27}$ Tiedemann, K. op. cit. ant., p. 1173.
} 
permitiría castigar a la persona jurídica por los delitos que se cometiesen en su seno y durante su mantenimiento, ya que al ser tales delitos resultado de la acumulación de procesos empresariales defectuosos se justificará que desencadenen la responsabilidad de la empresa actuando como meras condiciones objetivas de su punibilidad. ${ }^{28}$

No parece que ninguna de estas soluciones sea del todo convincente, máxime cuando las dos parecen querer sustentar la responsabilidad de las personas jurídicas atendiendo no a como actuaron u omitieron en el supuesto de hecho concreto del que se le quiere hacer responsable, sino a cómo desempeñaron su actividad empresarial con anterioridad a su producción, lo que presenta evidentes similitudes con la vieja y denostada teoría de la culpabilidad por la conducción de vida predicada en su día respecto a las personas físicas y que, como sucedió entonces, podría alejar al Derecho penal de las personas jurídicas del entorno del garantista Derecho penal del hecho para acercarlo al inaceptable Derecho penal de autor. $^{29}$

Por otra parte, algunos autores señalan que resulta realmente difícil sustentar que la existencia del defecto organizativo pueda ser el fundamento último de la culpabilidad de la empresa, ya que si lo fuese, ello tal vez permitiría fundamentar la apreciación de una culpabilidad propia de la entidad, pero también y al mismo tiempo estaría haciendo desaparecer el injusto del que se la trataría de responsabilizar, al tratar de fundamentarlo en una actuación (la realizada por algunos de sus órganos) que volvería a resultarle completamente ajena. ${ }^{30}$

No parece que se pueda fundamentar la culpabilidad de la persona jurídica sin atribuirle previamente un injusto propio y ello podría llevar a pensar que ese injusto se habría de derivar precisamente de su defectuosa organización. ${ }^{31}$ Sin embargo, tampoco esta aparente solución permitiría establecer un sistema de responsabilidad realmente paralelo al previsto para las personas físicas, por cuanto, si bien justificaría la existencia del injusto imputable a la entidad, también dejaría sin ningún contenido su juicio de culpabilidad, lo que llevaría a que las sanciones a aplicarle se sustentasen tan solo en la peligrosidad que habría manifestado con dicho hecho y, en consecuencia, haría que las sanciones o medidas que se le impusiesen tuviesen que ser consideradas como meras medidas de seguridad de naturaleza netamente inocuizadora y no como las auténticas penas que deberían acompañar al verdadero reconocimiento de su responsabilidad penal. ${ }^{32}$

\footnotetext{
${ }^{28}$ Heine, G. "Modelos de responsabilidad jurídico-penal..." cit. ant., pp. 47 y 51.

${ }^{29}$ En este sentido, se manifestaba Silva Sánchez, J. M. "La responsabilidad penal de las personas jurídicas...", pp. 337 y 338.

${ }^{30}$ Martínez-Buján Pérez, C. op. cit. ant., p. 240, entre otros.

31 Así lo entendía Gracia Martín, L. "La cuestión de la responsabilidad penal de las propias personas jurídicas" en op. cit. ant., pp. 132 y 133.

32 Silva Sánchez, J. M. "La responsabilidad penal de las personas jurídicas...”, p. 338. En similares términos se manifiesta también Feijoo Sánchez, B. en "La responsabilidad penal de las personas jurídicas...", ant. cit., p. 88.
} 
Galán - La responsabilidad penal de la persona jurídica...

Es más, incluso si se admitiese, atendiendo a la existencia del estado de necesidad preventivo de que hablaba Schünemann, que lo que se aplicaría a estos entes serían verdaderas penas sin culpabilidad, ${ }^{33}$ nos encontraríamos con que las normas que prohibirían la creación del Estado cuya vulneración supuestamente daría lugar a su aplicación, se dirigirían y se vulnerarían por sujetos individuales y no por tales entidades, con lo que al fin y al cabo volveríamos a sancionar a las personas jurídicas por hechos cometidos por un tercero diferente de ellas, siendo además evidente que su sanción se fundamentaría en la infracción de una norma de conducta (la que supuestamente les obliga a organizarse de forma correcta) distinta a la norma prohibitiva establecida en el tipo delictivo por el que se la vendría a sancionar, con lo que vulneraríamos el principio de legalidad al subsumir "...en la norma penal supuestamente infringida, una acción lesiva referida a otra norma, que es la norma de organización". ${ }^{34}$

Como se puede comprobar tras este breve resumen, las propuestas de creación de un sistema de responsabilidad penal propio de las personas jurídicas realizadas a lo largo del todavía inacabado debate doctrinal han sido numerosas y enriquecedoras, si bien hay que admitir que aún no han llegado a plasmarse en ninguna que responda a todos los problemas preventivos planteados en la sociedad actual, respetando al mismo tiempo las garantías materiales y procesales mínimas (principio de legalidad, inexistencia de la responsabilidad objetiva, responsabilidad por hecho propio, presunción de inocencia, etc.) que han de caracterizar cualquier sistema de imputación de responsabilidad penal de un verdadero Estado.

Pese a todo, nuestro legislador ha decidido atender a los incesantes requerimientos internacionales referidos a la necesidad de ampliar el campo de la posible responsabilidad penal de las personas jurídicas y ha optado por establecer un nuevo y más complejo sistema de imputación para dichas entidades mediante la aprobación de la todavía reciente LO 5/2010; con lo que parece querer dejar al margen cualquier polémica doctrinal relativa a esta cuestión, optando por mantener la misma postura que en su día manifestó su predecesor el legislador suizo cuando afirmó, precisamente en relación a esta materia, que a la hora de "... regular adecuadamente una situación que se reconoce como problemática, no es la dogmática, sino la voluntad del legislador la que decide si dicha regulación resulta permitida"."

\footnotetext{
33 Véase lo señalado a este respecto en la nota al pie $n^{\circ} 7$.

34 Schünemann, B. "La responsabilidad penal de las empresas y sus órganos...", cit. ant., pp. 148 y ss. En el mismo sentido, se manifestaba ya el mismo autor en "Responsabilidad penal en el marco de la empresa....", cit. ant., p. 29.

${ }^{35}$ Heine, G. "Modelos de responsabilidad jurídico-penal...", cit. ant., p. 44.
} 


\section{La persona jurídica ante el Derecho penal tras la Ley Orgánica 5/2010}

Como hemos apuntado, la reforma del sistema de responsabilidad penal de la persona jurídica efectuada por la Ley Orgánica 5/2010, de 22 de junio, trata de responder a las exigencias político criminales que llevaron a un importante sector de la doctrina nacional a recomendar y a múltiples normas inter- y supranacionales a exigir que nuestro ordenamiento estableciese un sistema de responsabilidad penal para dichos entes mucho más amplio y elaborado que el que aparecía contemplado en el ya derogado artículo 31.2 de nuestro Código Penal. ${ }^{36}$

La todavía reciente reforma de nuestro Código Penal realizada por la citada Ley Orgánica ha supuesto una auténtica revolución en lo que se refiere al sistema de responsabilidad penal de las personas jurídicas previsto en nuestro país, ya que no sólo ha ampliado la posibilidad de imputarles responsabilidad sacándola del encajonamiento en que la había mantenido el anterior artículo $31.2 \mathrm{CP}$, que sólo permitía que se pudiese apreciar respecto a la comisión de delitos especiales propios sancionados con penas de multa, sino que además les ha otorgado un complejo sistema de imputación de responsabilidad penal (art. 31 bis CP) y las ha dotado de un catálogo propio de penas (art. $33.7 \mathrm{CP}$ ) y de unas reglas autónomas de determinación de las mismas (art. 66 bis $\mathrm{CP}$ ); novedades todas ellas que además se han visto acompañadas por una reforma importante de las reglas de determinación de su posible responsabilidad civil derivada de delito (art 116.3 CP) y de una redefinición de las funciones y el ámbito de aplicación que habrán de tener a partir de ahora las denominadas consecuencias accesorias del art. 129 CP, que dejarán de resultar aplicables a la persona jurídica para serlo solo respecto a entes colectivos carentes de personalidad jurídica.

La reforma, por tanto, es de calado y afecta a numerosas cuestiones referidas al tratamiento que el Derecho penal español dará a las personas jurídicas.

Pese a lo importante y a lo interesante que resultan todos estos cambios, en el presente trabajo tan solo vamos a tratar de concretar y de fijar los parámetros que nuestro legislador ha establecido a la hora de fijar cuándo y bajo qué condiciones se podrá imputar responsabilidad penal a dichas entidades. Es decir, vamos a tratar de definir los criterios delimitadores del nuevo sistema de imputación de responsabilidad penal de las personas jurídicas; sistema que, como ya hemos apuntado, aparece contemplado en el nuevo artículo 31 bis de nuestro

\footnotetext{
36 De hecho, hablamos de reforma y no introducción de un sistema de responsabilidad penal por considerar que nuestro Código Penal ya contemplaba dicha responsabilidad en el, afortunadamente ya derogado, art. 31.2 CP; precepto que venía a establecer la responsabilidad directa y solidaria de la persona jurídica respecto al pago de las multas impuestas a la persona física que actuase en su nombre y representación en la comisión de delitos especiales propios y que ya tuvimos ocasión de comentar y criticar en un trabajo anterior. En concreto, en Galán Muñoz, A. "¿Societas delinquiere nec puniere potest? Algunas consideraciones críticas sobre el artículo $31.2 \mathrm{CP}$ ”, en RDPC $\mathrm{N}^{\circ} 18$ (2006), pp. 229 y ss.
} 
Galán - La responsabilidad penal de la persona jurídica...

Código Penal y que distingue dos posibles y diferentes niveles de imputación para dichas entidades.

Por una parte, el comentado artículo establece en su apartado primero que "...En los supuestos previstos en este Código, las personas jurídicas serán penalmente responsables de los delitos cometidos en nombre o por cuenta de las mismas, y en su provecho, por sus representantes legales y administradores de hecho o de derecho".

Como se puede comprobar el legislador español ha optado por establecer un sistema de numerus clausus a la hora de fijar los delitos por los que habrán de responder penalmente las personas jurídicas, ${ }^{37}$ si bien también ha dejado claro que dichos delitos habrán de ser materialmente cometidos por una persona física para poder generar la responsabilidad de tales entidades, lo que demuestra, a juicio de algunos autores, que se parte de un sistema de heterorresponsabilidad que impute normativamente a la persona jurídica un hecho de referencia realizado por un sujeto diferente, por una persona física. ${ }^{38}$

\footnotetext{
${ }^{37}$ En concreto, se prevé su posible responsabilidad respecto a los siguientes delitos tráfico ilegal de órganos humanos (art. 156 bis); trata de seres humanos (art. 177 bis); prostitución y corrupción de menores (art. 189 bis); descubrimiento y revelación de secretos (art. 197); estafa (art. 251 bis); insolvencias punibles (art. 261 bis); daños informáticos (art. 264); delitos contra la propiedad intelectual, el mercado y los consumidores (art. 288); lavado de dinero (art. 302); delitos contra la Hacienda Pública y la Seguridad Social (art. 310 bis); delitos contra los derechos de los ciudadanos extranjeros (art. 318 bis); delitos urbanísticos (art. 319); delitos contra los recursos naturales y medio ambiente (arts. 327 y 328); delitos relativos a la energía nuclear y las radiaciones ionizantes (art. 343); delitos relativos a las sustancias que pueden causar estragos (art. 348); delitos contra la salud pública (art. 369 bis); falsificación de tarjetas y cheques (art. 399 bis); cohecho (art. 427); tráfico de influencias (art. 430); corrupción de funcionarios públicos extranjeros e internacionales (art. 445); y terrorismo (arts. 570 quáter y 576 bis).

38 Zugaldía Espinar, J. M. en Fundamentos de Derecho penal. Parte General. Ed. Tirant lo Blanch. Valencia, 2010, p. 581, en idénticos términos, se manifiesta el mismo autor en "Societas delinquere potest (Análisis de la reforma operada en el Código Penal español por la LO 5/2010, de 22 de junio)", en La Ley Penal $\mathrm{N}^{\circ}$ 76, 2010, en www.laley.es (últ. vis. 10-7-2011). Así también, lo han entendido, entre otros, Muñoz Conde, F. / García Arán, M. quienes expresamente afirman que “...en el Código Penal español la persona jurídica responde por el hecho de otro”, en op. cit. ant., p. 631; Gómez Martín, V. en Comentarios al Código penal. Reforma LO 5/2010. Ed. Tirant lo Blanch. Valencia, 2011, p. 131; Orts Berenguer, E. / González Cussac, J. L. Compendio de Derecho penal. Parte General. Ed. Tirant lo Blanch. Valencia, 2010, p. 238; Zúñiga Rodríguez, L. "Responsabilidad penal de las personas jurídicas y criminalidad organizada", en Un Derecho penal comprometido. Libro homenaje al Prof. Dr. Gerardo Landrove Diaz. Ed. Tirant lo Blanch. Valencia, 2011, p. 1171; Dolz Lago, M-J. que señala que el sistema es un modelo de transferencia o vicarial en "Sobre el estatuto penal de la persona jurídica como sujeto responsable. A propósito sobre la circular de la fiscalía general del Estado 1/2011", La Ley No 7665, 2011, en www.laley.es (últ. vis. 10-7-2011), al igual que Sánchez Reyero, D. G. "Estudio sobre la responsabilidad de la persona jurídica, el doloso dependiente y el corporate compliance", La Ley No 7663, 2011, en www.laley.es (últ. vis. 10-7-2011) o Carbonell Mateu, J. C. /Morales Prats, F. quienes precisamente echan a faltar en este nuevos sistema la atribución de una responsabilidad por hecho propio de la persona jurídica, en op. cit. ant., p. 71.
} 
En concreto, la imputación del delito cometido en este primer nivel por la persona física a la jurídica se producirá cuando se den una serie de requisitos que podemos agrupar en personales y materiales.

Así, y en cuanto a los primeros, resulta evidente que el legislador ha limitado el círculo de personas que pueden generar responsabilidad a las personas jurídicas en este primer nivel de imputación al establecer que éstas tan solo responderán por los delitos cometidos por sus representantes legales o por sus administradores de hecho o de derecho; mientras que por lo que se refiere a lo que hemos calificado como requisitos materiales se condiciona su imputación a que tales actuaciones se hubiesen realizado "en nombre o por cuenta de ellas" y "en su provecho".

Ahora bien, este primer nivel de responsabilidad parece verse notablemente ampliado conforme a lo dispuesto en el segundo nivel contemplado en el mismo artículo donde se establece que "...En los mismos supuestos, las personas jurídicas serán también penalmente responsables de los delitos cometidos, en el ejercicio de actividades sociales y por cuenta y en provecho de las mismas, por quienes, estando sometidos a la autoridad de las personas físicas mencionadas en el párrafo anterior, han podido realizar los bechos por no haberse ejercido sobre ellos el debido control atendidas las concretas circunstancias del caso".

De nuevo nos encontramos con que el legislador prevé la posibilidad de imputar determinados delitos a la persona jurídica cuando concurran ciertos requisitos personales y materiales.

Así, y por lo que se refiere a los requisitos personales nos encontramos con que los sujetos que pueden cometer conductas delictivas imputables a las personas jurídicas, conforme a este segundo nivel, se caracterizan por el mero hecho de estar subordinados a la autoridad de las nombradas en el primero, es decir, por ser subordinados de los representantes legales y de los administradores de hecho o de derecho de tales entidades, lo que supone una significativa ampliación del grupo de sujetos que van a poder generar su responsabilidad al cometer delitos.

Sin embargo, esta ampliación del grupo de sujetos que pueden convertir a la persona jurídica en responsable de las conductas delictivas que cometan se va a ver en cierta medida compensada por el incremento de los requisitos materiales que se van a exigir para que ello suceda.

Aquí no bastará con que dichos sujetos actúen por cuenta y en provecho de la persona jurídica en cuestión, sino que además también tendrán que hacerlo actuando en el ejercicio de las actividades sociales propias de dichas entidades y habiendo cometido el hecho gracias a que sus superiores no hubiesen ejercido el control que deberían haber empleado sobre sus conductas atendiendo a las concretas circunstancias del caso. 
Galán - La responsabilidad penal de la persona jurídica...

Sea como fuese, y con independencia de lo que cada uno de estos requisitos de imputación conlleve, con lo hasta aquí comentado tendríamos que afirmar que el sistema de responsabilidad penal de nuestro Código Penal para las personas jurídicas se enfrentaría en principio a todos los problemas que caracterizan a cualquier sistema de heterorresponsabilidad y entre ellos, de forma destacada, a aquel que se deriva de que, al condicionar la posible responsabilidad penal de la persona jurídica a la constatación de la de una persona física, dejaría sin respuesta todos aquellos casos en los que no fuese posible encontrar a una persona física a la que se pudiese procesar o considerar culpable del hecho delictivo producido, con lo que no solventaría muchos de los principales problemas preventivos que estas entidades plantean como posibles estructuras organizadas de irresponsabilidad penal.

El legislador fue plenamente consciente de esta situación y para solucionarla introdujo dos preceptos que tratan de resolverla o cuando menos de paliarla.

Así, y en primer lugar, estableció en el apartado 2 del art. 31 bis CP que “... La responsabilidad penal de las personas jurídicas será exigible siempre que se constate la comisión de un delito que baya tenido que cometerse por quien ostente los cargos o funciones aludidas en el apartado anterior, aun cuando la concreta persona física responsable no baya sido individualizada o no haya sido posible dirigir el procedimiento contra ella"; mientras que, inmediatamente a continuación, en el apartado 3 del mismo artículo afirmó que "...La concurrencia, en las personas que materialmente hayan realizado los hechos o en las que los bubiesen hecho posibles por no baber ejercido el debido control, de circunstancias que afecten a la culpabilidad del acusado o agraven su responsabilidad, o el hecho de que dichas personas hayan fallecido o se bubieren sustraido a la acción de la justicia, no excluirá ni modificará la responsabilidad penal de las personas jurídicas, sin perjuicio de lo que se dispone en el apartado siguiente".

Es evidente que ambos preceptos tratan de corregir algunas de las carencias que se derivarían del establecimiento de un sistema de heterorresponsabilidad puro, introduciendo el primero de ellos una regla que permitiría responder a los casos de indeterminación de la persona física responsable del delito (p. ej., los derivados de votaciones secretas); mientras que el segundo independizaría la responsabilidad penal de la persona jurídica de la posible inexistencia de culpabilidad penal en dichas personas cuando se la pudiese localizar.

La responsabilidad penal de las personas jurídicas deja así de ser totalmente dependiente de la responsabilidad imputable a la persona física y pasaría a convertirse en una responsabilidad directamente predicable respecto de ella misma, ${ }^{39}$ hecho que ha llevado a otro sector de la doctrina a considerar que, en

\footnotetext{
39 Así lo señalan Muñoz Conde, F. / García Arán, M. quienes consideran la responsabilidad de la persona jurídica en el nuevo sistema como independiente de la física, precisamente, por poder
} 
REJ - Revista de Estudios de la Justicia - No 15 - Año 2011

realidad, no nos encontramos ante un verdadero sistema de heterorresponsabilidad, sino ante uno mixto "...que parte de la beterorresponsabilidad penal empresarial (responsabilidad por el becho ajeno) y se encamina hacia la autorresponsabilidad (responsabilidad penal por el hecho propio)". 40

Podría pensarse que esta combinación de criterios propios de los sistemas de auto y heterorresponsabilidad trataría de instaurar uno nuevo e híbrido que aunase todas las virtudes y eludiese todos los defectos que acompañaban a ambos modelos por separado.

Sin embargo, y como vamos a ver, no parece que lo consiga, ya que a poco que lo analicemos con algo de detenimiento, nos daremos cuenta de que el art. 31 bis CP continúa enfrentándose a muchos y a muy graves problemas.

Así, por ejemplo, nos encontramos con que el supuesto sistema mixto contemplado en dicho precepto continuaría sin dar una clara y adecuada razón del porqué la existencia y la gravedad de la responsabilidad penal de las personas jurídicas va a depender, siempre y en todo caso, de la actuación que realicen determinadas personas físicas. ¿Qué justifica que estas entidades tengan que responder, por ejemplo, por el delito de vertidos realizado por uno de sus representantes o empleados? ¿Cuál es el fundamento material que permite considerarla como responsable de un hecho que, al fin y al cabo, habría cometido un tercero? ¿Por qué podrían y tendrían que responder tanto de los delitos dolosos como de los imprudentes que cometiesen dichos sujetos? ¿Es que el legislador ha optado por reconocer la responsabilidad objetiva de la persona jurídica en determinados ámbitos delictivos? ¿No sería esto contrario al principio de culpabilidad?

Pero los problemas y cuestiones referidos a este nuevo sistema no acaban aquí. También se enfrenta a graves dificultades internas como las que se derivan de la propia coordinación de los dos niveles de imputación que, como hemos visto, contempla el vigente art. 31 bis.1 CP.

Si nos fijamos, en el primer nivel se hace a la persona jurídica responsable de las actuaciones delictivas realizadas por las personas que ejercen cargos superiores en su seno y tienen capacidad de decisión y competencia para comprometer a la empresa en el tráfico jurídico. Sin embargo, en el segundo se

predicarse incluso sin la condena de este último sujeto, en op. cit. ant., p. 630. En esta misma línea se pronuncian también Zugaldía Espinar, J. M. en Fundamentos de Derecho penal..., cit. ant., p. 582; Silva Sánchez, J. M. "La reforma del Código penal: Una aproximación desde el contexto", en La Ley $\mathrm{N}^{\circ}$ 7465, 201, en www.laley.es (últ. vis. 10-7-2011); Carbonell Mateu, J. C. /Morales Prats, F. op. cit. ant., p. 72; Gómez Martín, V., op. cit. ant., p. 131 o Sánchez Reyero, D. G., op. cit. ant., entre otros.

40 Gómez-Jara Díez, C. "La responsabilidad penal de las personas jurídicas en la reforma...", cit. ant. En el mismo sentido, Feijoo Sánchez, B. en "La responsabilidad penal de las personas jurídicas...", ant. cit., p. 85. 
Galán - La responsabilidad penal de la persona jurídica...

permite que se les pueda atribuir responsabilidad por el mero hecho de que dichos sujetos no hubiesen ejercido el debido control sobre sus subordinados, lo que supone que la realización de una conducta que podría resultar incluso individualmente irrelevante a efectos penales por parte de dichos superiores también podría abrir las puertas a la responsabilidad de toda la entidad.

La pregunta es inmediata. Si estamos ante un sistema que en principio es de atribución de responsabilidad, ¿no debería ser más grave la responsabilidad de la persona jurídica respecto a los delitos cometidos dolosamente por sus administradores y representantes que la que se le tendría que imputar por sus actuaciones meramente imprudentes o incluso permitidas $?^{31}$ Pero es que además, ¿no parecería lógico pensar que si la pena aplicable a la persona jurídica va a depender de la gravedad del delito cometido por la física, cuanto más cerca de los órganos directivos de la persona jurídica se cometa el delito a imputar mayor habría de ser su responsabilidad por el mismo ${ }^{42} ¿$ ¿Cómo justificar entonces que el legislador no haya distinguido a efectos punitivos supuestos de hecho dotados de una gravedad tan aparentemente diferente $?^{43} \dot{ }{ }^{N}$ No resulta esto contrario al principio de proporcionalidad?

Pero los problemas no acaban aquí. La aparente mezcla de sistemas contenida en el art. 31 bis 1 CP lleva a que se nos plateen otras aparentes intrasistémicas.

Así, por ejemplo, y como hemos visto, el nuevo sistema trata de huir de los problemas que la heterorresponsabilidad plantea, desligando la responsabilidad de las personas jurídicas de la de las físicas al establecer que no va a ser necesario que se individualice o que se pueda perseguir penalmente a la persona física que cometió el delito para que se pueda imputar responsabilidad por su realización a la jurídica (art. 31 bis. 2 CP) y afirmando que las circunstancias que afecten a la

\footnotetext{
${ }^{41}$ En este sentido afirma Silva Sánchez, J. M. que “... se observa una contradicción entre los delitos cometidos por acción de los administradores y representantes y los cometidos por la omisión de vigilancia de éstos sobre personal subordinado. Mientras que los primeros se ven como delitos, en general, dolosos, en los segundos, los cometidos por inferiores jerárquicos por no haberse ejercido sobre ellos el debido control, parece contemplarse una conducta imprudente de la persona física controladora. Ahora bien, entonces resulta discutible que lo transferido a la persona jurídica sea una «omisión del debido control» -en principio, imprudente- y ello dé lugar a una responsabilidad dolosa de la persona jurídica". En "La reforma del Código Penal: Una aproximación desde el contexto", cit. ant.

42 Así, por ejemplo, Nieto Martín, A. señala que el nivel jerárquico del autor individual del delito es un indicador bastante fiable del grado de culpabilidad de la empresa, ya que ésta aumenta "...a medida que crece el grado jerárquico de la persona individual responsable, por lo que los deberes de autoorganización son mayores en relación con los comportamientos delictivos que realiza la cúspide empresarial que los de los subodrinados", en op. cit. ant., p. 163.

43 En este sentido, señala Zugaldía Espinar, J. M. que la distinción en dos niveles de la imputación de responsabilidad tenía su fundamento en el Derecho Comunitario que los diferenció precisamente para distinguirlos a efectos de pena, cosa que no hizo el régimen penal establecido para las personas jurídicas por la LO 5/2010, lo que a su modo de ver haría que dicho dualismo careciese de sentido. En Fundamentos de Derecho penal..., cit. ant., p. 590.
} 
culpabilidad de aquellas no incidirán en modo alguno en la posible responsabilidad imputable a éstas (art. 31 bis, 3 CP).

Todo parece indicar entonces que el Derecho penal quiere distinguir y separar a dos sujetos, a dos destinatarios diferentes de sus normas y de las responsabilidades que se podrían derivar de sus incumplimientos. A dos sujetos que, de hecho, estarían dotados cuando menos de una culpabilidad y una punibilidad distintas y propias.

Sin embargo, toda esta construcción parece tambalearse desde el momento en que el propio art. 31 bis 2 CP afirma que "...Cuando como consecuencia de los mismos hechos se impusiere a ambas la pena de multa, los jueces o tribunales modularán las respectivas cuantias, de modo que la suma resultante no sea desproporcionada en relación con la gravedad de aquéllos".

De nuevo nos asaltan las dudas. ¿No estábamos ante dos sujetos diferentes, dotados de una culpabilidad y responsabilidad diferentes? ¿Qué problema de proporcionalidad puede derivarse entonces de la posible acumulación de dos sanciones de multa a dos sujetos distintos incluso si

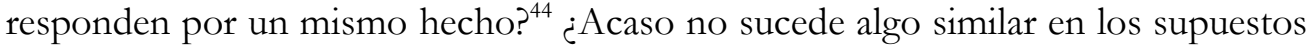
de coautoría sin que se aprecie infracción alguna del principio de proporcionalidad? ${ }^{45}$ De hecho, y en sentido contrario, chacer depender la magnitud de la pena de multa aplicable a cada uno de estos sujetos de la predicable respecto al otro no supone determinar la pena propia conforme al merecimiento de pena predicable respecto de un tercero? Es más, e incluso admitiendo que se diesen problemas de proporcionalidad en estos casos, ¿por qué la proporción se restablecería tan solo en el caso de la multa? ¿Por qué no se afirma respecto a otras posibles penas aplicables a estos entes? ¿Cómo se restablecerá la proporcionalidad? ¿Se rebajará la pena de la persona jurídica? ¿La de la física? ¿La de ambas? ${ }^{46}$

A juicio de algunos autores, lo que aquí sucede es que el legislador ha partido de una incorrecta y contraproducente visión de la aplicación del principio de ne bis in idem a estos supuestos. Por más que se empeña en separar y en afirmar

\footnotetext{
44 Así lo señala Zugaldía, quien manifiesta que incluso cuando se sostuviese que se sanciona a ambos por un mismo hecho y con un mismo fundamento continuaríamos encontrándonos ante dos personas (incluso patrimonios) diferentes, con lo que la posible acumulación de sanciones nunca se plantearía problema de proporcionalidad, ya que la pena a imponer a cada una de ellas, al ser individual y personal, no podría depender de la que se impusiera a ningún tercero. En Fundamentos de Derecho penal..., cit. ant., pp. 591 y ss. También considera incomprensible esta prescripción Bacigalupo, S. "Los criterios de imputación de la responsabilidad penal de los entes colectivos y de sus órganos de gobierno (art. 31 bis y 129 CP) (1)", en La Ley $\mathrm{N}^{\circ}$ 7541, 201, en www.laley.es (últ. vis. 10-7-2011).

${ }^{45}$ Carbonell Mateu, J. C. /Morales Prats, F. op. cit. ant., p. 75.

${ }^{46}$ Cfr. Mata Barranco, N. "La responsabilidad penal de las personas jurídicas", en Reforma del Código penal. Perspectiva económica tras la entrada en vigor de la ley orgánica 5/2010 de 22 de junio. Situación jurídicopenal del Empresario. Ed. El Derecho. Madrid, 2010, p. 83.
} 
Galán - La responsabilidad penal de la persona jurídica...

que nos encontramos ante dos sujetos penales diferentes, no ha podido evitar seguir concibiendo a la persona jurídica como una vulgar entelequia, como una mera ficción, que oculta tras su personalidad jurídica a una o varias personas físicas que podrían llegar a ser doblemente sancionadas por el mero hecho de haber cometido sus delitos en el seno de las empresas que dirigían o gestionaban, ${ }^{47}$ lo que le ha llevado de nuevo a tratar a la persona jurídica como a un mero instrumento de la comisión de delitos de las físicas y no como a un verdadero sujeto activo y responsable de su realización al que se podrá imputar una responsabilidad penal directa, propia y perfectamente acumulable con la que se le podría atribuir a aquéllos.

De hecho, y como señala Gómez Tomillo, el legislador parece manifestar una cierta mala conciencia respecto a esta posible acumulación de sanciones pecuniarias, pensando sobre todo en aquellas situaciones en las que las personas jurídicas sancionadas son pequeñas y presentan un carácter familiar; supuestos en los que le cuesta sostener que estemos ante dos sujetos activos diversos, con lo que se demuestra que, pese a sus muchas manifestaciones en sentido contrario, sigue sin asumir plenamente que las personas jurídicas responden por su propio injusto y tienen su propia culpabilidad. ${ }^{48}$

El legislador estaría así dando constantes pasos hacia delante y hacia atrás. Establece un sistema de heterorresponsabilidad por atribución de hecho ajeno e introduce criterios correctores propios de los sistemas de autorresponsabilidad. Fija una responsabilidad directa y acumulada para las personas jurídicas e inmediatamente a continuación implanta una regla que relativiza dichas características de la responsabilidad de tales entidades. Parece concebir a la persona jurídica como posible sujeto activo de determinados delitos, diferente y autónomo de la persona física que materialmente lo comete y, a renglón seguido, afirma que la sanción acumulada de ambos puede dar lugar a problemas de proporcionalidad obligando a los tribunales a tenerla en cuenta a la hora de concretar la pena de multa aplicable a cada uno de dichos sujetos.

Es este constante vaivén el que ha llevado a algunos autores, como a Bacigalupo, a afirmar que en realidad "... el legislador no ha elaborado un modelo de imputación en sentido estricto - como se explica en la Exposición de Motivos-", sino que simplemente ha descrito "...la determinación de unos hechos que permitirán la atribución de éstos a las personas jurídicas", lo que resulta inaceptable, "... ya que de ser suficiente para la responsabilidad penal de las personas jurídicas o entes colectivos la existencia exclusiva de un becho de conexión, ello constituiría un modelo de responsabilidad objetiva incompatible con los principios del Derecho Sancionador".

\footnotetext{
47 Zugaldía Espinar, J. M. en Fundamentos de Derecho penal..., cit ant., pp. 592 y ss.

48 Gómez Tomillo, M. op. cit. ant., pp. 171 y ss. En similares términos se manifiesta también, Gómez Martín, V. op. cit. ant., p. 134 y Carbonell Mateu, J. C. /Morales Prats, F. op. cit. ant., p. 75.

${ }^{49}$ Bacigalupo, S. Op. cit. ant.
} 
¿Es esto cierto? ¿No existe ningún sistema definido de imputación de la responsabilidad penal de las personas jurídicas tras las prescripciones contenidas en el nuevo artículo 31 bis de nuestro Código Penal? ¿Realmente estamos ante un caso excepcional y más que cuestionable de reconocimiento de una responsabilidad penal objetiva por hechos ajenos?

\section{Fundamento y naturaleza del sistema de imputación de responsabilidad penal de las personas jurídicas en el art. 31 bis $\mathbf{C P}$}

Como acabamos de ver, la reforma realizada por la LO 5/2010 ha introducido una serie de preceptos referidos a la aplicación de penas a las personas jurídicas, sobre cuyo concreto fundamento y naturaleza discute la doctrina. Para unos, dicha reforma ha establecido un verdadero sistema de heterorresponsabilidad. Otros, sin embargo, consideran que ha creado uno que presenta algunos elementos propios de los sistemas de autorresponsabilidad, lo que les lleva a defender que su naturaleza mixta, aunque tampoco faltan voces que simplemente niegan que tras la citada reforma exista un verdadero sistema de imputación que se pueda tener por tal, lo que determina que se cuestione la propia legitimidad y constitucionalidad de todo lo establecido en dicha reforma con respecto a dichas entidades.

El indiscutible punto de partida de la posible responsabilidad de las personas jurídicas, conforme a lo establecido en nuestro Código Penal tras la citada reforma, es la comisión por parte de determinadas personas físicas de un hecho que resulte típicamente antijurídico conforme a lo establecido en alguno de los delitos respecto a los que se prevé la posibilidad de imputar responsabilidad penal a las personas jurídicas. ${ }^{50}$

Es evidentemente que esta premisa no debe ni puede suponer derogación alguna del principio de culpabilidad ni del de personalidad de las penas; principios que proscriben cualquier posibilidad de que el Derecho penal pueda atribuir una responsabilidad objetiva a un sujeto por un hecho que le resulte completamente ajeno, al haber sido realizado por otro sin su intervención.

\footnotetext{
${ }^{50}$ En efecto, como bien señala Mata Barranco, N. aun cuando el art. 31 bis 2 CP permita imputar responsabilidad a la persona jurídica en los casos en los que no se haya podido individualizar la persona física que cometió el delito o en los que no se haya podido actuar contra ella, ello no supone que no se tenga que acreditar la existencia de la acción típicamente antijurídica de la que se le va a hacer responsable. La actuación individual que dé lugar al injusto individual ha de existir, ya que si éste no concurre "...no cabe hablar de una responsabilidad de la persona jurídica; porque se estaría exigiendo la misma por algo que no es ilicito" en op. cit. ant., pp. 82 y 83. En el mismo sentido se manifiestan Carbonell Mateu, J. C. /Morales Prats, F. quienes señalan que "...no parece explicable que el hecho típico, perpetrado por persona fisica, declarado además justificado (no antijurídico) acabe siendo antijurídico al ser proyectado al plano de la responsabilidad de la persona jurídica", en op. cit. ant., pp.76. En el mismo sentido, Feijoo Sánchez, B. en "La responsabilidad penal de las personas jurídicas..." ant. cit., p. 90.
} 
Galán - La responsabilidad penal de la persona jurídica...

El problema se centrará entonces en buscar qué fundamentaría la responsabilidad de la persona jurídica cuando se produzca alguno de dichos hechos. Es decir, tenemos que buscar qué justificará que la persona jurídica pueda y tenga que responder por el injusto delictivo que habría cometido una persona física distinta de ella; cuestión para la que se han propuesto diferentes posibles respuestas por parte de nuestra doctrina.

Un sector de la misma ha considerado que lo que hace que la conducta antijurídica de la persona física en cuestión pueda llegar a generar responsabilidad a la jurídica es el simple hecho de que tal comportamiento se hubiese realizado por determinados sujetos en el contexto empresarial, societario o asociativo propio de la entidad, ya que éste sería el dato que determinaría que el denominado hecho de referencia o de conexión (Anknüpfungstat) se le pueda y se le deba atribuir o imputar normativamente ${ }^{51}$ al ser considerado como un producto de "...la conjunción, de la sinergia de la actuación de la persona física con las especiales posibilidades estructurales y medios de la personas jurídica". ${ }^{52}$

Sin embargo, y frente a esta postura, otro sector doctrinal ha entendido que la constatación de la realización de uno de estos hechos en tales ámbitos por parte de alguna de las personas físicas mencionadas en el art. 31 bis CP no resulta en modo alguno suficiente para considerar al injusto producido como propio de la persona jurídica y niegan también que el hecho de que se hubiesen realizado además en su nombre, por su cuenta y en su provecho o interés puedan cambiar tal consideración.

A su modo de ver, estos comportamientos ajenos son "...presupuestos de la responsabilidad de las personas jurídicas, pero no son su verdadero fundamento", pues "...si se exige algún tipo de hecho propio de la persona física representada para que la actuación de su

\footnotetext{
${ }^{51}$ En este sentido, Zugaldía Espinar, J. M. considera que se cumplirá este requisito cuando se haya actuado en ejercicio de unas competencias sociales que se posean, en el seno de la persona jurídica y dentro de su marco estatutario "Societas delinquere potest..." cit. ant. Mata Barranco, N. por su parte, afirma en esta línea que la exigencia normativa de que la actuación delictiva de la persona física se haya realizado "en nombre o por cuenta de" la persona jurídica cuya responsabilidad va a generar "... no puede significar otra cosa que una actuación que asuma las directrices de comportamiento de la persona jurídica, que no se oponga a sus normas de conducta o protocolos de cumplimiento, interpretando "en nombre o por cuenta de" en el sentido de plasmando la voluntad de modo tal que pueda entenderse que aunque estemos bablando de responsabilidades diversas, la de la persona jurídica sólo tendrá sentido si la persona física actúa como prolongación de la anterior, como brazo ejecutor de las decisiones de la persona jurídica...” en op. cit. ant., p. 76; mientras que Gómez-Jara Díez, C. señala que se deben desechar criterios exclusivamente civilistas y entender que se da una de estas conductas cuando "...la acción del representante constituya la implementación de una política empresarial - no siendo por tanto necesaria una autorización expresa de la persona jurídica-", en "La responsabilidad penal de las personas jurídicas en la reforma..." cit. ant.

${ }^{52}$ Gómez Tomillo, M. op. cit. ant., pp. 52 y 53.
} 
representante le genere responsabilidad, lo mismo debe exigirse respecto a la persona jurídica" en estos casos. ${ }^{53}$

No bastará, por tanto, con constatar el injusto típico de la persona física para trasladarlo sin más a la persona jurídica. Ésta también tendría que haber realizado un injusto típico propio; injusto que, en opinión de algunos de estos autores, habría de fundamentarse en la constatación de la existencia de un fallo o defecto en la organización empresarial que sería el que permitiría que la persona jurídica pudiese ser tenida por responsable del delito finalmente producido. ${ }^{54}$

Como se puede comprobar, las dos posturas comentadas no son sino una nueva manifestación más del evidente enfrentamiento que existe entre las dos principales propuestas doctrinales referidas a la posibilidad de atribuir responsabilidad penal a las personas jurídicas ya que tuvimos ocasión de diferenciar y comentar al comienzo de este trabajo.

Por una parte estarán quienes defienden que la persona jurídica ha de responder por el mismo injusto que cometa la persona física que actuó por su cuenta y en su provecho, lo que supone reconocer que nuestro Código contiene un sistema de heterorresponsabilidad en el que se darán todos los problemas que resultan propios a dicha clase de sistemas; mientras que por otra se encontrarían aquellos que tratan de buscar un fundamento autónomo y propio para el injusto de la persona jurídica acercando el sistema del art. 31 bis $\mathrm{CP}$ a los de autorresponsabilidad y, por tanto, también a los problemas que les son propios.

El enfrentamiento entre ambas propuestas era previsible y casi inevitable, máxime si se tiene en cuenta que el tenor literal del art. 31 bis CP recoge y mezcla, como hemos visto, elementos propios de ambos posibles modelos de imputación.

Se parte de la necesidad de la comisión de un hecho injusto por parte de un tercero para imputarle responsabilidad a la persona jurídica, pero al mismo tiempo se afirma que la responsabilidad penal de esta última es autónoma e independiente de la predicable respecto a aquél, hasta el punto de que se le podrá atribuir responsabilidad aun cuando no se pueda concretar qué concreto sujeto lo cometió o incluso, si pudiendo hacerlo, no se le pudiese considerar culpable o procesar por ello.

Se delimita a determinados sujetos físicos (los representantes, los administradores de hecho o de derecho), cuyas actividades delictivas podrán dar lugar a la responsabilidad penal de las personas jurídica, pero a renglón seguido se cita a otros cuyos delitos sólo generarán su responsabilidad si se constata que los pudieron cometer porque no se ejerció sobre ellos el debido control, lo que

53 Gómez-Jara Díez, C. “La responsabilidad penal de las personas jurídicas en la reforma...” cit. ant.

${ }^{54}$ Ibidem. 
Galán - La responsabilidad penal de la persona jurídica...

parece aludir a la existencia de un defecto de organización de la propia persona jurídica como fundamento último su propia responsabilidad. ${ }^{55}$

¿Cómo articular todas estas prescripciones normativas aparentemente enfrentadas sin incurrir en una aparente contradicción?

Quienes abogan, conforme a la corriente actualmente mayoritaria, por considerar al art. 31 bis.1 CP como un precepto fundamentador de un verdadero sistema de heterorresponsabilidad de las personas jurídicas, entienden que lo establecido en su segundo nivel de imputación no resulta óbice alguno para mantener su postura, ya que, a su modo de ver, estamos ante una norma que establece un claro deber de vigilancia para los directivos y representantes respecto a las personas físicas que están bajo su autoridad (los subordinados), entendiéndose entonces que cuando los superiores omiten sus deberes de supervisión de alguna manera será la propia entidad la que los habría omitido, al constituir "los directivos el alter ego de la persona jurídica".

Sin embargo, con ello continuaría sin explicarse por qué razón la persona jurídica habría de responder por una conducta que, pese a ser una omisión, seguiría resultándole ajena ni se daría tampoco solución a los graves problemas de proporcionalidad interna que, como vimos, tendría que afrontar este supuesto nuevo sistema de heterorresponsabilidad, que permitiría que en el primer nivel de imputación del art. 31 bis.1 CP se hiciese responder a la persona jurídica por las acciones y omisiones delictivas y mayoritariamente dolosas cometidas por sus directivos y en el segundo, sin embargo, se les pudiese atribuir la misma responsabilidad por unas omisiones de dichos sujetos que podrían ser consideradas, todo lo más y no siempre, como meramente imprudentes. ${ }^{57}$

En este mismo sentido, la comentada postura también daría lugar a situaciones de descoordinación normativa extrasistémicas difícilmente justificables.

Así, por ejemplo, resultaría llamativo que precisamente en el único supuesto en que nuestro Código parece reconocer, de forma general, la

\footnotetext{
55 Así lo afirman Carbonell Mateu, J. C. /Morales Prats, F. Op. cit. ant., p. 73; Muñoz Conde, F. / García Arán, M. op. cit. ant., p. 630 o Bacigalupo, S., entre otros, si bien esta última autora considera que "...El defecto de organización no sólo debe ser requisito de la responsabilidad por infracción del deber de vigilancia de los administradores sobre sus subordinados, sino el presupuesto general que legitima la aplicación de una pena a una persona jurídica", lo que la llevó a considerar tal defecto como fundamento de la culpabilidad de la persona jurídica y no como sustento de su injusto propio, op. cit. ant. Una postura similar es mantenida también por Gómez Tomillo, M. quien considera que también respalda dicha consideración el hecho de que el art. 31 bis 4.c) CP permita atenuar la pena de las personas jurídicas cuando establezca medidas eficaces para prevenir y descubrir futuros delitos cometidos con sus medios o bajo su cobertura, op. cit. ant., pp. 141 y ss.

${ }^{56}$ Gómez-Jara Díez, C. "La responsabilidad penal de las personas jurídicas en la reforma...” cit. ant.

${ }^{57}$ En similares términos, Silva Sánchez, J. M. En "La reforma del Código Penal: Una aproximación desde el contexto" cit. ant.
} 
responsabilidad penal omisiva de los directivos de las personas jurídicas con respecto a conductas delictivas realizadas por terceros subordinados a su autoridad que pudieron evitar (el delito del art. $318 \mathrm{CP}$ ), sea precisamente uno de los supuestos en los que la ausencia de previsión de la posible incriminación de las personas jurídicas por tales conductas se eche más en falta por parte de la doctrina. ${ }^{58}$

¿Cómo es posible que el ejemplo más grave de omisión respecto a conductas delictivas de terceros de quienes supuestamente actúan como alter ego de la persona jurídica no pueda generarle responsabilidad y actuaciones que podrían ser completamente atípicas sí lo pudiesen hacer?

Alguna respuesta a todo este sinsentido podemos encontrar, sin embargo, si prestamos un poco más de atención a lo establecido en el propio art. 31 bis 1 CP.

Si lo hacemos nos percataremos de que, en realidad, el deber legal de control contenido en su segundo nivel de imputación no obliga a evitar que las personas sometidas a la autoridad de los representantes y administradores de la persona jurídica (los subordinados) realicen delitos, sino solo a impedir que los cometan "en el ejercicio de actividades sociales y por cuenta y en provecho de las mismas", es decir, en el ámbito del giro empresarial propio de la empresa, lo que dota a la exigencia normativa de que el delito que se vaya a imputar a la persona jurídica se cometa por dichas personas físicas de una dimensión completamente diferente.

Esta delimitación no está tratando de concretar qué sujetos individuales habrán de realizar la infracción del deber de control que daría lugar a la responsabilidad del ente colectivo. Lo que se pretende es precisar y concretar hasta dónde llegará la obligación de control de riesgos de la persona jurídica, extendiéndola hasta aquellas conductas que supongan la ejecución de actividades sociales llevadas a cabo por personas físicas, incluso ajenas a su organigrama (p. ej., autónomos, directivos o empleados de subcontratas, etc.), ${ }^{59}$ pero que se habrían

\footnotetext{
58 Así, por ejemplo, Muñoz Conde, F. / García Arán, M. llegan a atribuir dicha ausencia a un "olvido" del legislador, en op. cit. ant., p. 629.

59 También consideran que la responsabilidad de la persona jurídica podría derivarse de las actuaciones realizadas por estos sujetos no vinculados de forma permanente a la estructura empresarial, pero que sí desarrollarían una actividad por su cuenta y bajo el control de quienes la gestionan o representan, Gómez Tomillo, M. op. cit. ant., p. 67 y Gómez Martín, V. en op. cit. ant., p. 133. En contra de la postura aquí defendida, se manifiesta Feijoo Sánchez, B. que entiende que solo podrán tener relevancia a estos efectos las actuaciones realizadas por personas "...que tengan una relación laboral o de Alta Dirección con la persona jurídica", en "La responsabilidad penal de las personas jurídicas..." ant. cit., pp. 100 y 101, lo que, a nuestro juicio, no se corresponde con el fundamento material que se defiende en este trabajo con respecto a la responsabilidad de tales entidades y olvida el hecho de que cada vez es más frecuente que éstas actúen utilizando los servicios de sujetos que, si bien podrían ser autónomos o incluso estarían adscritos a otras entidades, estarían realizando actividades propias de su giro empresarial, por su cuenta, en su
} 
Galán - La responsabilidad penal de la persona jurídica...

llevado a cabo gracias a la estructura y recursos de la empresa y bajo el control y la supervisión de quienes tendrían la capacidad legal o fáctica necesaria para poder haberlo impedido (los administradores de hecho o de derecho y los representantes).

Se establecería así un deber de supervisión o control que compele a vigilar lo que se efectúa al amparo del ejercicio de su propia actividad empresarial; deber que, por otra parte, si bien aparece expresamente contemplado en el segundo nivel de imputación del art. 31 bis.1 CP, también está recogido y reflejado, a nuestro juicio, en las reglas que perfilan el primero, como lo demuestra el hecho de que también en ellas se deje claro que las personas jurídicas solo responderían de los delitos que cometan los administradores o representantes actuando "en nombre" o "por cuenta" y "en provecho" de dichas entidades; expresiones que demuestran que no se las podrá responsabilizar por el cargo que ostentase el concreto autor de tales delitos, sino por el hecho de que éste los hubiesen cometido en un ámbito que la persona jurídica podría y debería haber controlado, el de la actividad empresarial desarrollada al amparo de su nombre y/o con la ayuda de sus recursos.

También resulta significativo, en este sentido, que en ambos niveles de imputación se exija que los delitos imputables a las persona jurídicas se hayan de cometer "en provecho de las mismas"; expresión que, a nuestro modo de ver, determina que el deber de control que se les impone tampoco esté referido a cualquier forma de criminalidad que las personas físicas nombradas en el art. 31 bis CP pudiesen realizar desde su seno o aprovechándose de sus estructuras y medios, sino tan sólo a aquella que se hubiese efectuado para beneficiarla de alguna forma, lo que supone que los citados entes colectivos no tendrán que controlar ni deberán responder por la criminalidad que simplemente se venga a dar en su seno ("criminalidad en la empresa"), tampoco por aquella que se pueda efectuar contra sus intereses ("criminalidad contra la empresa"), sino tan sólo por la que se integren dentro del concepto de lo que la doctrina ha llamado "criminalidad de la empresa" y que podrían y deberían haber evitado. ${ }^{60}$

provecho y bajo la autoridad de aquellos que la representaban y dirigían, con lo que entrarían de lleno en el grupo de sujetos contemplados en el segundo nivel de imputación del art. 31 bis.1 CP.

60 También conecta la interpretación de este elementos del art. 31 bis CP con el concepto de criminalidad de empresa Zugaldía Espinar, J. M. "Societas delinquere potest..." cit. ant.; concepción que, conforme a lo aquí sostenido, nos lleva a entender que estamos ante un nuevo elemento objetivo delimitador del deber $\mathrm{y}$, por tanto, también del ámbito de posible responsabilidad omisiva de la entidad y no ante una exigencia de naturaleza subjetiva referida al autor del delito generador de responsabilidad, como sostienen González-Cuéllar Serrano, N. / Juanes Peces, A. en "La responsabilidad penal de las personas jurídicas y su enjuiciamiento en la reforma de 2010. Medidas a adoptar antes de su entrada en vigor", en La Ley $\mathrm{N}^{\circ}$ 7541, 201, en www.laley.es (últ. vis. 10-7-2011). Sobre esta cuestión véase también lo comentado por Gómez Tomillo, M. op. cit. ant., pp. 84 y ss. Lo importante, a nuestro juicio, es que la actividad delictiva se haya efectuado por una persona física que ejerza competencias sociales cuando lo realice y que además las utilice de una forma que objetivamente tienda a aportar beneficios económicos, competitivos o de cualquier otra clase a la empresa que se las otorgó, no para obtener un beneficio 
Parece, por tanto, que por fin podríamos haber encontrado un posible fundamento normativo de la responsabilidad de la persona jurídica común a los dos niveles de imputación contemplados en el artículo 31 bis CP y diferente del que sustentaría la de la persona física que hubiese cometido el delito que la viniese a generar.

La responsabilidad penal de la persona jurídica se fundamentaría en la infracción del deber colectivo de control de riesgos que el citado precepto dirigiría a todos los entes dotados de personalidad jurídica. Así lo indicaría también el hecho de que el establecimiento de medidas preventivas, posteriores a la comisión de los delitos por los que se las condene, permita atenuar su responsabilidad con independencia del nivel de imputación que hubiese utilizado para imputársela (art. 31 bis 4. d)). ${ }^{61}$ Sin embargo, para poder afirmar que esto es realmente así, y que en consecuencia, todo el sistema de responsabilidad de las personas jurídicas se sustenta en la posible infracción del referido deber, se hace necesario comprobar si tal fundamento se ajusta realmente al tenor literal del resto de preceptos que conforman dicho sistema $\mathrm{y}$, sobre todo, si permite responder a todos los problemas y aparentes contradicciones a los que éste parecía enfrentarse.

\section{Problemas con respuesta en el nuevo sistema de responsabilidad penal de las personas jurídicas}

Como acabamos de ver, es el propio tenor literal del artículo 31 bis CP el que nos indica cual podría ser el pilar básico del nuevo sistema de responsabilidad penal de la persona jurídica, ya que es precisamente en dicho precepto en donde se

particular para sí mismo o para otro, perjudicando a terceros o incluso a la propia entidad. Mantienen esta concepción objetiva, amplia y no meramente económica del elemento "en provecho", el propio Gómez Tomillo, M. op. cit. ant., pp. 86 y 87; Zugaldía Espinar, J. M. "Societas delinquere potest..." cit. ant.; Feijoo Sánchez, B. en "La responsabilidad penal de las personas jurídicas..." ant. cit., pp. 98 y 99 o Gómez Martín, V. op. cit. ant., p. 133; En contra se manifiesta, por ejemplo, Gómez-Jara Díez, C. quien considera que esta expresión obliga a la efectiva consecución del provecho, para apreciar su concurrencia "La responsabilidad penal de las personas jurídicas en la reforma..." cit. ant. Sobre la interesante diferenciación entre la criminalidad de la empresa y en la empresa, desarrollada en el seno de la doctrina alemana por el profesor Shünemann, B. véase su trabajo titulado "Strafdogmatische und Kriminalpolitische Grundfragen der Unternehmenskriminalität”. Wistra 2, 1982, pp. 41 y ss., traducido y publicado en español bajo el título "Cuestiones básicas de dogmática jurídico-penal y de política criminal acerca de la criminalidad de empresa" en ADPCP T. 41, 1988; o lo comentado al respecto por Martínez-Buján Pérez, C. en op. cit. ant., pp. 67 y ss. o Bajo Fernández, M. / Bacigalupo Saggese, S. op. cit. ant., p. 148.

${ }^{61}$ De hecho, algunos autores, como Gómez-Jara Díez, C. en "La responsabilidad penal de las personas jurídicas en la reforma..." cit. ant., Alonso Gallo, J. op. cit. ant., p. 155 o Feijoo Sánchez, B. en "La responsabilidad penal de las personas jurídicas..." ant. cit., pp. 130 y 135 señalan que la existencia de esta atenuante, apreciable cuando se implanten medidas de control después de la comisión del delito, lleva a que se tenga que entender que si dichas medidas se hubiesen implantado antes deberían haber llevado a su irresponsabilidad penal. 
Galán - La responsabilidad penal de la persona jurídica...

condiciona su posible responsabilidad al hecho de que el delito del que se le haga responsable se haya realizado en su beneficio, dentro de su ámbito de actividad y por personas que gocen de las competencias necesarias para ejercitarla, con lo que entendemos que se deja claro que lo que se impone es un mandato de control de los recursos tanto personales, como materiales e inmateriales que conforman la propia persona jurídica, para impedir que puedan ser utilizados en la comisión de tales delitos.

La persona jurídica, como concentración de recursos que es, es vista como una posible fuente de riesgos penalmente relevantes que puede facilitar o incluso incentivar la comisión de delitos, consideración que lleva al Derecho penal a obligar a quienes están implicados en su actividad y tienen el control último sobre dicha fuente generadora de peligros a que lo ejerzan de forma responsable y no se desentiendan totalmente de lo que puedan hacer con ella aquellos en los que hubiesen delegado o depositado la capacidad de poder utilizarla total o parcialmente.

El punto de partida del sistema sería por tanto la existencia de un mandato dirigido a la persona jurídica como ente colectivo para que realice aquellas conductas y establezca aquellas medidas que estando a su alcance podrían impedir que se pudiesen cometer delitos en el desarrollo de su actividad, con lo que se la convierte en garante y en posible responsable, no de la conducta delictiva o no cometida por la persona física incardinada en su estructura organizativa o sometida al control o autoridad de sus administradores o representantes, sino de la omisión que ella misma habría cometido al no haber controlado de forma adecuada el ámbito de actividad que se encontraba bajo su dominio y que estaba obligada a vigilar.

Ahora bien, una vez que se sustenta la responsabilidad del ente colectivo en la existencia de una posible omisión por su parte, resulta necesario, como no podía ser de otra forma, comprobar que dicho ente puede realmente cumplir con el deber que le obligaba a actuar, ya que, como es sabido, solo existe una omisión cuando no se efectúa la acción que la norma penal exige que se haga, existiendo, sin embargo, la posibilidad real de ejecutarla. ${ }^{62}$

\footnotetext{
${ }^{62}$ No compartimos, por tanto, en modo alguno la postura defendida en su día por Rodríguez Ramos, L. cuando afirmó que pese a que es “...la acción en sentido propio -comisión- es impensable que la protagonice una persona jurídica, separada de la conducta de las personas físicas que la componen, porque aquélla carece realmente de capacidad de acción por si misma(...)", ello no supone que no pueda realizar omisiones, ya que "...La omisión, en cambio, tiene una naturaleza ideal, hipotética, pues consiste en un "no hacer", "en la nada”, en algo inexistente sólo presente en la mente de quien la piense(....)” En "¿Cómo puede delinquir una persona jurídica en un sistema penal antropocéntrico? (La participación en el delito de otro por omisión imprudente: pautas para su prevención)" La Ley N 7561 2011, en www.laley.es (últ. vis. 86-2011). A nuestro juicio, sin embargo, la omisión parte de dos premisas. Por una parte de la existencia de un mandato u orden normativa de actuar, sin el cual la omisión no existiría. Por otra de la posibilidad real del sujeto al que se exige que actúe de realizar lo que se le pide, ya que en caso de que ésta no existiese no podría decirse que haya omitido conducta alguna ni que haya
} 
Este requisito básico y común a toda omisión nos enfrenta de nuevo a un viejo y conocido problema; el referido a la vieja y nunca cerrada cuestión de si las personas jurídicas gozarían de una capacidad propia de acción o si, por el contrario, carecerían ella, con lo que no solo no podrían actuar, sino que tampoco podrían omitir.

¿Puede una persona jurídica, un ente colectivo, evitar activamente delitos y, por tanto, también omitir dicha evitación si le es exigida por el ordenamiento jurídico?

Como ya vimos, esto fue negado, entre otros por Schünemann, quien señalaba que aun cuando llevásemos la infracción normativa generadora de la responsabilidad de la persona jurídica a una norma de conducta que la obligase a organizarse correctamente, nos encontraríamos con que dicho mandato tampoco podría ser incumplido por la entidad, puesto que, al final, solo podría ser infringido por la actividad que realizasen una o varias personas físicas. ${ }^{63}$

Nada se puede objetar a dicha observación, si bien creemos que la misma parte de una premisa equivocada, como es la de volver a tratar de aplicar criterios de imputación propios del sistema penal de responsabilidad individual a una imputación de naturaleza netamente colectiva, que por definición ha de responder a parámetros diferentes y, en su caso, paralelos a los de aquél.

Aquí, a nuestro modo de ver, no estamos ya ante una norma de determinación individual que obligue a los sujetos individuales a actuar de una concreta manera, permitiendo considerarles responsables si no lo llegasen a hacer. Aquí estamos ante una norma colectiva dirigida a la persona jurídica como ente diferente de los concretos individuos que la integran o trabajan para ella y que solo los vinculará en la medida en que actúen en el seno o al amparo de alguna de sus destinatarias iniciales; es decir, al amparo de alguna de las personas jurídicas a las que el art. 31 bis CP se dirige. ${ }^{64}$

incumplido el mandato normativo que le afectaba, hecho que nos lleva entender que para poder afirmar que la persona jurídica puede omitir, se tiene que reconocer que también podrá actuar. En esta línea, Muñoz Conde, F. / García Arán, M. señalan que “...La omisión en sí misma no existe. La omisión es la omisión de una acción que se puede hacer y, por eso mismo, está referida siempre a una acción determinada, cuya realización constituye su esencia. (...) De aqui se desprende que el sujeto autor de la omisión debe estar en condiciones de poder realizar la acción, si no existe tal posibilidad de acción, por las razones que sean, no puede hablarse de omisión", op. cit. ant., p. 238.

${ }^{63}$ Vid. Supra.

${ }^{64}$ En este sentido, se ha de destacar que tampoco todas las personas jurídicas son destinatarias de las prescripciones establecidas en el art. 31 bis CP conforme a lo establecido en el apartado 5 de dicho artículo, donde se establece que "Las disposiciones relativas a la responsabilidad penal de las personas jurídicas no serán aplicables al Estado, a las Administraciones Públicas territoriales e institucionales, a los Organismos Reguladores, las Agencias y Entidades Públicas Empresariales, a los partidos políticos y sindicatos, a las organizaciones internacionales de derecho público, ni a aquellas otras que ejerzan potestades públicas de 
Galán - La responsabilidad penal de la persona jurídica...

En efecto, estamos ante una verdadera norma de determinación o de conducta que a diferencia del resto de las que configuran el Derecho penal no estaría ya dirigida exclusivamente a orientar el comportamiento de un sujeto individual, sino que intentaría dirigir el de todos aquellos que se integran simultánea o sucesivamente en entes de naturaleza colectiva, como las personas jurídicas y gozan además de la capacidad de incidir en su organización y actuación. En concreto, sería una norma de determinación, y no una meramente valorativa de la situación en la que se encuentra la persona jurídica como algunos han sostenido, ${ }^{65}$ que obligaría de forma colectiva, acumulativa e incluso sucesiva a todas las personas físicas que individual o colectivamente gozasen de la capacidad de controlar y de decidir sobre la posible actividad de la jurídica, a que hiciesen lo que estuviese en su mano para evitar que dicha actividad pudiese dar amparo y/o sustentar la comisión de delitos, siendo, por tanto, una norma que les obligaría a organizarse y actuar de forma coordinada con el resto de los que gozaban o gozaron de dichas capacidades, para tratar de conseguirlo.

El nuevo art. 31 bis CP intentaría convertir a las personas jurídicas, como estructuras organizativas diferentes y que pueden llegar a trascender a los concretos individuos que las conforman, en colaboradoras obligatorias de la tarea preventiva de delitos propia del Derecho penal, para lo cual obligará colectivamente a todas las personas físicas que tienen capacidad real de poder intervenir en la dirección de sus actividades (desde los socios fundadores o no, hasta los administradores y sus representantes que podrían ejercen dicha competencia, total o parcialmente, por delegación), a hacer cuanto esté en su mano para evitar que tales actividades puedan amparar y facilitar delitos.

No estamos ya, por tanto, ante un mandato individualmente dirigido a cada una de dichas personas físicas en concreto, sino ante uno que se dirige de forma colectiva a todas a la vez y que les obliga a controlar y a responder no sólo por lo que ellas mismas hacen, sino también por lo que dejasen hacer a aquellas otras con las que compartían o en las que delegaron su dominio social.

\footnotetext{
soberania, administrativas o cuando se trate de Sociedades mercantiles Estatales que ejecuten políticas públicas o presten servicios de interés económico general. En estos supuestos, los órganos jurisdiccionales podrán efectuar declaración de responsabilidad penal en el caso de que aprecien que se trata de una forma jurídica creada por sus promotores, fundadores, administradores o representantes con el propósito de eludir una eventual responsabilidad penal". Sobre el cuestionable fundamento de esta limitación y los problemas que su efectiva aplicación planteará, véase lo comentado por Muñoz Conde, F. / García Arán, M. op. cit. ant., pp. 628 y 629; Gómez-Jara Díez, C. "La responsabilidad penal de las personas jurídicas en la reforma..." cit. ant.; Gómez Martín, V. op. cit. ant., pp. 131 y 132; Zúñiga Rodríguez, L. "Responsabilidad penal de las personas jurídicas..." cit. ant., p. 1173; Gómez Tomillo, M. op. cit. ant., pp. 35 y ss.; Orts Berenguer, E. / González Cussac, J. L. op. cit. ant., p. 239 o Carbonell Mateu, J. C. /Morales Prats, F. op. cit. ant., p. 78 o Feijoo Sánchez, B. en "La responsabilidad penal de las personas jurídicas..." ant. cit., pp. 75 y ss., entre otros.

${ }^{65}$ Cfr. Silva Sánchez, J. M. "La responsabilidad penal de las personas jurídicas...”, pp. 344 y ss.
} 
El Derecho penal atiende así al carácter colectivo, desconcentrado y difuso del dominio que caracteriza a la estructura empresarial como posible fuente de peligros, que tantos problemas ha dado a su sistema de imputación individual, creando una norma de determinación colectiva que obliga a las personas individuales que la integran y dominan, aunque sea parcialmente, a controlar no sólo lo que ellas hacen, sino también lo que realizan u omiten quienes (co)dominan con ellas la actividad social o lo hacen por su delegación, con lo que se las convierte en garantes no solo de sus conductas sino también de las ajenas que podrían haber evitado, para conseguir que la unión de sus respectivas acciones y omisiones individuales no puedan llegar a amparar o facilitar la realización de delitos, precisamente como consecuencia del desapego y desinterés que algunos o todos ellos podrían mostrar por la forma en la que se decidiese dirigir la actividad empresarial.

Los accionistas o los socios, como colectivo, no pueden ya invertir y desentenderse de lo que haga el resto de socios o sus administradores o representantes con lo invertido, esperando cómodamente y sin ningún temor los beneficios que las decisiones, incluso delictivas, de dichos sujetos les podrían reportar. Tienen que involucrarse en el control del uso que sus delegados hagan de sus recursos, ya que si no lo hiciesen puede que no lleguen a ser considerados individualmente responsables del delito que su desidia favoreció, pero sí podrían llegar a padecer los efectos que la imposición de una pena a la entidad podría tener sobre sus propios patrimonios o derechos. ${ }^{66}$

Ahora bien, una vez que hemos determinado quiénes y por qué pueden generar la responsabilidad penal de las personas jurídicas como entes colectivos, aún tendríamos que determinar cómo deberían actuar dichos sujetos para poder quedar a salvo de cualquier posible responsabilidad penal. Es decir, tenemos que determinar dónde se encuentra el nivel de riesgo permitido establecido para las personas jurídicas en nuestro Código Penal y dónde comienza, por tanto, su posible responsabilidad.

\footnotetext{
${ }^{66}$ En efecto, estamos ante una norma que establece un mandato y fija nivel de riesgo permitido diferente y paralelo para los entes colectivos del establecido para los concretos sujetos individuales que los integran o dirigen, por lo que no será extraño que la conducta que infrinja dicho mandato sea una acción u omisión que si bien no superaría por sí misma el umbral de lo penalmente permitido para el concreto individuo que la realizó, sí permita entender que superó el nuevo límite marcado por el mandato colectivo; como tampoco lo será que la posible conducta o defecto preventivo que permitiese apreciar la infracción del mandato colectivo pueda ser producto de varias actuaciones $\mathrm{y} / \mathrm{u}$ omisiones de personas físicas que consideradas individualmente serían penalmente irrelevantes o incluso resultarían perfectamente lícitas. Sin embargo, tanto en uno como en otro supuesto se habría dado una infracción del nuevo mandato colectivo de vigilancia establecido por el art. 31 bis CP para las personas jurídicas, siendo precisamente dicha infracción la que permitiría imputarle responsabilidad penal a toda la entidad como ente colectivo jurídicamente responsable de su producción.
} 
Galán - La responsabilidad penal de la persona jurídica...

Alguna pista al respecto podemos volver a encontrar en el propio tenor literal del art. 31 bis.1 CP.

En concreto, la encontramos cuando se afirma que se podrá imputar responsabilidad penal a la persona jurídica si se constata que quienes cometieron el delito estando bajo la autoridad de quienes ejercían el dominio social instrumental, lo pudieron realizar "...por no haberse ejercido sobre ellos el debido control atendidas las concretas circunstancias del caso".

A nuestro modo de ver, con dicha expresión se está estableciendo un claro referente a la hora de fundamentar la tipicidad subjetiva del ente colectivo. Se habla del ejercicio del "debido control" y con ello se está fijando al deber objetivo de cuidado como referente fundamentador del injusto subjetivo de dichas entidades, ${ }^{67}$ al tiempo que se afirma que dicho deber se ha de fijar "atendiendo a las circunstancias concretas del caso", lo que supone que no existe una modalidad única de conducta diligente o permitida, sino que, como sucede en todos los delitos imprudentes, dicha conducta se ha de definir atendiendo a todas las circunstancias, tanto objetivas como subjetivas, que se den en el caso concreto.

Parece evidente entonces que no se podrá exigir el mismo nivel de diligencia preventiva a una gran multinacional que disponga de múltiples recursos materiales y personales para evitar delitos que a una pequeña empresa familiar que carezca de ellos, del mismo modo que tampoco se podrá exigir que establezca las mismas medidas preventivas de delitos medioambientales una empresa destinada al tratamiento de residuos altamente contaminantes que una que no ejerza dicho tipo de actividades, por más que su giro empresarial alguna vez pueda llegar a ocasionar alguna afección delictiva del medio ambiente.

No existen parámetros generales que sirvan para definir el nivel de lo permitido para las personas jurídicas, ni parece, por tanto, que el establecimiento de programas de cumplimiento o de códigos de conductas generales o estándar resulte suficiente para garantizar la impunidad de dichas entidades. ${ }^{68}$ Cada una

\footnotetext{
${ }^{67}$ En similares términos, Gómez-Jara Díez, C. "La responsabilidad penal de las personas jurídicas en la reforma..." cit. ant.

${ }^{68}$ Compartimos, por tanto, las palabras de Quintero Olivares, G. cuando señalaba que “...La idea de que un código de conducta interno puede obrar como escudo protector está totalmente fuera de lugar. El control debido y los reglamentos o códigos de conducta de una empresa son cuestiones que circulan por vías diferentes, por cercanas que estén en su sentido último", en "Personas jurídicas, entes, grupos, y sus individuos. Su responsabilidad penal tras la reforma de la Ley Orgánica 5/2010" en El Cronista del Estado Social y democrático de Derecho, $\mathrm{N}^{\mathrm{O}}$ 22, 2011, p. 9. Incluso los defensores de la implantación de los programas de cumplimiento, como Alonso Gallo, J. aceptan que “... Los programas de cumplimiento efectivos no garantizan que la empresa no incurrirá en responsabilidad penal. Esta eventualidad dependerá de las circunstancias del caso concreto y de la valoración que hagan los Tribunales sobre la diligencia de la empresa y la eficacia del programa. Esta valoración implicará siempre, inevitablemente, un juicio ex post del Tribunal, por mucho que la valoración del cumplimiento de las exigencias de cuidado debido teóricamente deba hacerse, como destaca la teoría general del delito, a partir de criterios ex ante (...)”. En op. cit. ant., p. 159.
} 
REJ - Revista de Estudios de la Justicia - No 15 - Año 2011

tiene que fijar programas preventivos adecuados a sus concretas circunstancias, tamaño, actividad, etc., lo que hará que tanto los tribunales como, sobre todo, las propias entidades hayan de fijar los concretos niveles de lo permitido atendiendo a criterios de exigibilidad y razonabilidad, obligándolas así a tener que preocuparse por aplicar medidas realmente preventivas y no unas que sólo aparenten serlo. ${ }^{69}$

Nos encontraríamos, por tanto, ante una responsabilidad penal colectiva de la persona jurídica que, conforme a los parámetros utilizados para las personas físicas, tendría que ser considerada como de naturaleza imprudente, ${ }^{70}$ naturaleza

69 Evidentemente, y como señala Nieto Martín, A. se corre el riesgo de que se establezcan estándares de exigibilidad preventiva demasiado bajos por parte de nuestros tribunales como consecuencia de su inexperiencia en esta materia, lo que podría afectar a la efectividad preventiva del propio sistema, en op. cit. ant., p. 175, pero esto puede suceder en casos aislados y en los momentos iniciales de implementación del sistema, ya que en la mayoría de las actividades realmente peligrosas existen protocolos y reglas preventivas extrapenales que los jueces podrán tener en cuenta a la hora de fijar el concreto nivel de riesgo permitido de cada entidad y donde ello no suceda, serán las propias exigencias de los socios de las entidades, tendentes a minimizar el riesgo de cualquier posible merma patrimonial, incluso de las derivadas de delitos, las que llevarán a que se concreten unos niveles de riesgos preventivos colectivos permitidos adecuados, realistas y especializados por sectores de actividad que permitirán iniciar el único camino que consideramos factible para establecer programas preventivos realistas y eficaces.

${ }^{70}$ En este mismo sentido se manifiesta, por ejemplo, Rodríguez Ramos, L. op. cit. ant., si bien, hemos de señalar que calificamos la conducta de la persona jurídica como imprudente por analogía con la tradicional diferenciación imprudencia/dolo del Derecho penal individual no estrictamente aplicable al de las personas jurídicas. Como hemos visto, lo que fundamentaría la tipicidad subjetiva del injusto de estas entidades sería el hecho de que habrían infringido el deber objetivo de cuidado colectivo que les correspondería sin concurrir ninguno de los elementos psíquicos que se exigirían para poder apreciar una conducta de su parte que pudiese ser tenida como dolosa, siendo precisamente esta delimitación de su tipicidad subjetiva la que acercará su injusto al propio de los delitos imprudentes cometidos por las personas físicas. En las conductas de las personas jurídicas, a diferencia de lo que sucede con las de las personas físicas, no pueden concurrir los elementos psicológicos que configuran al dolo como forma de imputación subjetiva diferente y más grave que la imprudencia, con lo que se deben rechazar todos los intentos realizados hasta la fecha que han tratado precisamente de encontrar una especie de dolo colectivo en la entidad partiendo de la concurrencia en su seno de un supuesto e inexistente conocimiento colectivo, de una representación colectiva del peligro o, lo que es peor, de una mera imputación funcional basada en la concepción social del hecho realizado que incluso permitiría prescindir de forma completa del conocimiento real del autor. No le falta razón, por tanto, a Nieto Martín, A. cuando señala que “... El intento de buscar el dolo de la corporación muestra con claridad el peligro existente al intentar hormar la responsabilidad colectiva con los criterios del derecho penal individual: la degradación de los conceptos de imputación subjetiva tradicionales con el fin de que puedan acomodarse a ambos tipos de responsabilidad". En op. cit. ant., pp. 161 y 162. En efecto, las personas jurídicas del art. 31 bis CP nunca podrán actuar con un verdadero dolo colectivo. Esta forma de dolo no existe realmente y su búsqueda lo único que puede conseguir es que se llegue a desvirtuar esta modalidad de imputación propia de las personas físicas hasta hacerla prácticamente irreconocible. De hecho, incluso si todos los miembros e integrantes de la entidad cuya conducta tuviésemos que valorar hubiesen actuado con un verdadero dolo de cometer delitos, parece que lo más lógico sería pensar que nos tendríamos que salir del ámbito de aplicación de este precepto para adentrarnos en el de aquellos otros que se ocupan de las asociaciones ilícitas o de las organizaciones y grupos criminales; delitos cuya concurrencia con el 
Galán - La responsabilidad penal de la persona jurídica...

que, a nuestro modo de ver, se ajusta perfectamente a los dictados de nuestro Código Penal y consigue que el sistema adquiera unos niveles de coherencia interna desconocidos hasta el momento.

Así, y en primer lugar, dicha naturaleza responde perfectamente al hecho de que el nuevo art. 31 bis CP haya establecido un sistema de numerus clausus a la hora de fijar los delitos respecto a los que se podría aplicar, ya que ello se corresponde con la opción adoptada por nuestro legislador en el artículo $12 \mathrm{CP}$ con respecto al resto de delitos imprudentes. ${ }^{71}$ Pero es que además, y por otra parte, tal naturaleza también se coordina perfectamente con que el sistema del art. 31 bis CP sea un sistema que solo se podrá activar cuando se haya llegado a producir aquel resultado que vendría a completar su injusto; es decir, cuando se haya llegado a materializar la contribución delictiva imprudente que la entidad podía y estaba obligada a evitar.

En efecto, en nuestra opinión, el delito cometido por la persona física supone la materialización de la contribución delictiva que la entidad estaba obligada a evitar. La persona jurídica, como ya vimos, no está obligada a impedir que ciertas personas físicas cometan determinados delitos. Lo que tiene que evitar es que dichos delitos se puedan cometer al amparo de su estructura y/o aprovechándose de sus recursos, con lo que resulta lógico pensar que sólo si no lo hace y de su omisión se deriva la producción de un delito cometido gracias a los medios que dejó indebidamente de controlar, se podrá entender que se ha completado el injusto típico imprudente del que se la tendría que responsabilizar. ${ }^{72}$

sistema de responsabilidad general de la persona jurídica planteará múltiples y muy difíciles problemas, como señala Quintero Olivares, G. op. cit. ant., pp. 10 y ss, que, sin embargo, no podemos analizar en este concreto momento, ya que su estudio requeriría de un trabajo prácticamente monográfico que, como fácilmente se comprenderá, sobrepasa con mucho el objeto de estudio del presente trabajo. En cualquier caso, y para tener una visión global sobre las distintas propuestas realizadas sobre el "dolo de las personas jurídicas" véase, lo comentado por Nieto Martín, A. op. cit. ant., pp. 155 y ss o por Gómez-Jara Díez, C. "El modelo constructivista de autorresponsabilidad penal empresarial", cit. ant., pp. 141 y ss, entre otros.

${ }^{71}$ Consideramos, por tanto, que el art. 31 bis 1 CP contempla y describe una modalidad específica y muy delimitada de comportamientos imprudentes colectivos, lo que determina que si bien todos los elementos delimitadores de dicha conductas aparezcan generalmente contemplados en el referido precepto, también obliga a que su posible sanción tenga que aparecer expresamente contemplada en aquellos delitos en los que resulte viable, ya que sólo así se responderá adecuadamente a la exigencia general establecida por el art. 12 CP. No existirá, por tanto, problema alguno de incompatibilidad entre lo establecido en este último artículo y lo contemplado en el nuevo 31 bis de nuestro Código Penal, frente a lo que sostenían Mata Barranco, N. op. cit. ant., p. 76 o Gómez Martín, V. op. cit. ant., p. 134 y por ello resultará, perfectamente viable castigar conforme al mismo conductas de naturaleza meramente imprudentes.

72 Consideramos, por tanto, a diferencia de lo que hace Quintero Olivares, G. Op. cit. ant., p. 8, que la persona jurídica no responde por no haber impedido los delitos, en la mayoría de supuestos dolosos, cometidos por la física, sino por haber contribuido de forma omisiva e imprudente a su producción, lo que nos permite eludir las aparentes contradicciones y problemas que el citado autor encontraba en el sistema español, ya que ni se tendría que admitir que se pueda generar un delito 
No existiría entonces desconexión alguna entre el injusto de la persona jurídica y el delito cometido por la física (bastará con demostrar la imputación objetiva entre la omisión efectuada y la contribución delictiva producida), tampoco habrá ya problema a la hora de justificar porque la mayor gravedad de dicho delito tendrá que redundar en una mayor responsabilidad de la entidad colectiva en que se cometió (mientras más grave sea el delito cometido mayor desvalor de resultado tendrá el injusto imputable a la entidad), con lo que la propuesta de interpretación aquí sostenida resolverá algunos de los reproches que más frecuentemente se han planteado a los sistemas de autorresponsabilidad empresarial, dotando al sistema español de una cierta preeminencia sobre los mismos.

Sin embargo, las ventajas de esta interpretación no acaban aquí.

Como fácilmente se puede deducir, partimos de una interpretación que hace responsable a la persona jurídica de un injusto que le es propio, lo que obliga a entender que cuando se la condene conforme a los parámetros contemplados en el art. 31 bis CP también se la tenga que condenar como corresponsable civil del daño ocasionado junto con las personas físicas que también pudieran llegar a ser condenadas por los hechos que generaron su responsabilidad (no se olvide que no siempre será necesaria dicha condena para generar la responsabilidad penal de la persona jurídica), con lo que se justificará que el artículo $116.3 \mathrm{CP}$ las convierta en responsables civiles solidarias del daño ocasionado junto a tales personas físicas, sin que, a nuestro modo de ver y frente lo que señala parte de la doctrina ${ }^{73}$ puedan reclamar o repercutir sobre ellas todo lo pagado, ya que al ser la persona jurídica también cocausante y corresponsable del daño producido, siempre le corresponderá una cuota propia de responsabilidad cuyo reintegro nunca podrá reclamar al resto de condenados. ${ }^{74}$

Por otra parte, la interpretación propuesta también serviría para evitar la aparente infracción del principio de proporcionalidad que, a juicio de algunos autores, se daría entre los dos niveles de imputación contemplados en el art. 31 bis CP.

\footnotetext{
doloso como consecuencia de un mero descontrol, ni se tendría que fundamentar la supuesta responsabilidad dolosa de la persona jurídica en la mera infracción de normas de cuidado que, por definición, estarían ideológicamente orientadas hacia la prudencia y la prevención.

73 Así, Gómez Tomillo, M. que señala que los socios podrían reclamar las pérdidas sufridas contra los administradores como consecuencia de su gestión deficitaria. op. cit. ant., p. 195, lo que supondría olvidar que también ellos, como colectivo, serían corresponsales de tal gestión.

74 Resulta necesario, por tanto, determinar la cuota correspondiente a la persona jurídica, hecho que, por otra parte, y a diferencia de lo que señala Gómez Tomillo, M., nos lleva a considerar que no se producirá la disminución del efecto preventivo que la responsabilidad civil ex delicto tendría sobre las personas físicas a la que él mismo alude. op. cit. ant., pp. 194 y 195, ya que el que se permita que la víctima pueda dirigirse directamente contra la persona jurídica exigiéndole el pago de la indemnización total, no impedirá que ésta pueda posteriormente repercutir la parte que no le corresponda sobre la física, haciendo así efectiva también su responsabilidad.
} 
Galán - La responsabilidad penal de la persona jurídica...

No es que en el primer nivel se castigue a la persona jurídica por algunos delitos dolosos y en el segundo por la mera realización de conductas imprudentes o no diligentes.

En realidad, en ambos niveles se sanciona a la persona jurídica por una omisión propia de naturaleza imprudente referida al control sobre los riesgos derivados de su actividad, con lo que no debe sorprender que ambos niveles se asimilen a efectos de pena, ni que el único referente de entre los contemplados en el art. 66 bis $1^{\circ} \mathrm{CP}$ que parezca aludir a la gravedad del hecho realizado por dichas entidades a la hora de determinar su pena, sea aquel que se refiere a la valoración del puesto que ocupó en ella la persona física que infringió el deber de control y no al que ocupaba quien efectivamente cometió el delito individual que daría lugar a su responsabilidad.

Lo que determina la gravedad subjetiva del injusto de la persona jurídica es la intensidad de la infracción del deber de cuidado que se ha de ejercer al dirigir su actividad, ${ }^{75}$ infracción que será más grave, entre otras cosas y como apunta el referido precepto, cuanto mayor sea el dominio o capacidad de control que tengan sobre su estructura la persona o el grupo de personas físicas que dejaron de vigilar adecuadamente el riesgo que la misma generaba.

Pero es que además y en esta misma línea, la interpretación propuesta también nos permitirá dar adecuada respuesta a otro de los problemas de proporcionalidad a los que parecería enfrentarse el nuevo art. 31 bis CP.

En concreto, nos servirá para dotar de sentido y de justificación al mandato legislativo que obliga a los jueces a modular las penas de multa simultáneamente impuestas a las personas físicas y jurídicas responsables de un delito, ya que al fundamentar la responsabilidad empresarial en la infracción de un deber difuso y, en su caso, colectivo de impedir delitos, tendremos que entender que el injusto omisivo producido por dicha infracción resultará inherente y se verá completamente absorbido por el que se habría de imputar al sujeto que lo incumplió precisamente por ser autor individual del delito que debería haber evitado como integrante de la entidad.

\footnotetext{
${ }^{75}$ Entendemos en tal sentido, que la gravedad de la infracción del deber de cuidado realizada por la persona jurídica en la omisión del deber de control de riesgos que se le atribuye, habrá de influir en la responsabilidad que se le impute y consecuentemente también en la pena que se le aplique. Es por ello que consideramos acertada la postura sostenida por Rodríguez Ramos, L., según la cual se deberá de fijar en la imprudencia grave la frontera mínima de la responsabilidad penal de la persona jurídica, ya que, como bien afirma el referido autor, ello responderá al carácter excepcional de la responsabilidad de tales entidades y también al hecho de que solo se predique respecto a delitos del libro II del Código Penal, donde sólo se prevé el castigo de dicha modalidad de imprudencia, quedando la leve adscrita a ciertas faltas. En op. cit. ant. También se decanta por exigir la constatación de la infracción grave del deber correspondiente a la empresa, para apreciar su responsabilidad evitando que la misma se genere por cualquier pequeña carencia organizativa, Heine, G. "Modelos de responsabilidad jurídico-penal...”, cit. ant., p. 64.
} 
Resulta evidente que no se puede castigar a los responsables de un delito por su comisión y por la infracción del posible deber de impedirlo que le pudiese corresponder sin infringir el principio de ne bis in idem y esto es precisamente lo que trata de evitar la previsión contenida en el art. 31 bis 2 de nuestro Código Penal cuando establece que el juez ha de modular las cuantías de las penas de multa correspondientes a las personas físicas y jurídicas cuando éstas se impongan como consecuencia de los mismos hechos. Trata de evitar que la acumulación de estas sanciones pueda llegar a infringir el principio de proporcionalidad, como sucedería, por ejemplo, cuando el administrador y socio único de una persona jurídica unipersonal que hubiese cometido un delito, pudiese ver duplicada o multiplicada la sanción pecuniaria que le correspondería pagar por el mero hecho de haberlo efectuado utilizando los medios de la entidad que le pertenecía.

Cierto es que a efectos civiles nos encontramos ante dos patrimonios jurídicamente separados y diferenciados, ${ }^{76}$ pero no lo es menos que en supuestos como el comentado el sujeto en cuestión vería cómo la merma patrimonial que tendría que sufrir como consecuencia de su actuación se podría ver notablemente incrementada con respecto a la que pagaría cualquier otra persona que hubiese realizado el mismo delito que él, por el mero hecho de haberlo efectuado utilizando unos elementos y mecanismos que le pertenecían, pero a los que había otorgado personalidad jurídica independiente, lo que no parece de recibo y determina que el artículo 31 bis $2 \mathrm{CP}$ obligue al juez a tener en cuenta este tipo de situaciones para que la aplicación acumulada de los dos sistemas de responsabilidad penal contemplados en nuestro Código (el individual y el colectivo) no dé lugar a incrementos punitivos injustificados y, por tanto, desproporcionados para los individuos que se encontrasen en este tipo de situaciones.

\section{Las sombras del sistema}

Hasta el momento hemos tratado de dar una interpretación adecuada y coordinada al que sin lugar a dudas supone el más decidido, valiente, y desarrollado intento de dar respuesta al siempre cuestionado tema de la posible responsabilidad penal de las personas jurídicas realizado en nuestro ordenamiento jurídico.

Por fin estamos ante una declaración clara e incuestionable de su posible responsabilidad y ante un sistema que, como hemos visto, aporta nuevas e interesantes propuestas para dotar de una respuesta político-criminal adecuada al reto que dichas entidades presentan al Moderno Derecho penal.

\footnotetext{
${ }^{76}$ Zugaldía Espinar, J. M. en Fundamentos de Derecho penal... ant. cit., p. 591 y el mismo autor en "Societas delinquere potest..." cit. ant.
} 
Galán - La responsabilidad penal de la persona jurídica...

Ahora bien, no todo son luces en este nuevo sistema. También existen muchas sombras que deben ser eliminadas lo antes posible por el bien de la efectividad del propio sistema.

Así, por ejemplo, resulta absolutamente inexplicable que la entrada en vigor del completo sistema de responsabilidad de las personas jurídicas introducido en nuestro Código por la LO 5/2010 no se haya visto acompañada por una paralela reforma de la Ley de Enjuiciamiento Criminal que otorgue una carta de naturaleza adecuada y dote de las debidas garantías al nuevo papel que tales entidades están llamadas a desempeñar en el proceso penal. ${ }^{77}$

Menos cuestionable nos parece, sin embargo, el hecho, criticado por algunos autores ${ }^{78}$ de que el sistema de responsabilidad de dichos entes sea un sistema de numerus clausus, dado que, a nuestro modo de ver, el reconocimiento de dicha responsabilidad supone una importante reducción del riesgo penalmente permitido que sólo se puede legitimar en casos excepcionales, ${ }^{79}$ lo que, sin embargo y por otra parte, no impide que consideremos que tal vez sería conveniente replantearse la elección de los concretos delitos en los que se prevé la aplicación del comentado sistema, ya que parece obvio que nuestro legislador ha optado, en dicha elección, más por tratar de responder a las exigencias comunitarias que por intentar atender a las verdaderas necesidades preventivas a las que se enfrenta nuestra sociedad, lo que, por ejemplo, le ha llevado a contemplar dicha forma de responsabilidad en delitos como los de descubrimiento y revelación de secretos y no en otros como los delitos contra los derechos de los trabajadores, los de vertidos medioambientales imprudentes y otros muchos en los

\footnotetext{
${ }^{77} \mathrm{La}$ necesidad de una reforma procesal paralela a la penal ha sido puesta de manifiesto por la mayor parte de la doctrina como, por ejemplo, Zugaldía Espinar, J. M. en Fundamentos de Derecho penal, cit. ant., p. 593; Carbonell Mateu, J. C. /Morales Prats, F., op. cit. ant., p. 85; Mata Barranco, N., op. cit. ant., p. 77; Bacigalupo, S., op. cit. ant.; Zúñiga Rodríguez, L., "Responsabilidad penal de las personas jurídicas...” cit. ant., pp. 1178 y ss. En este sentido, parece que dicha deficiencia puede ser pronto paliada con la aprobación y entrada en vigor de la ley de medidas de agilización procesal, cuyo artículo primero modifica varios preceptos de la Ley de Enjuiciamiento Criminal para dar un primer tratamiento procesal penal (tal vez no el más adecuado, pero por lo menos uno) al nuevo papel que las personas jurídicas están llamadas a jugar en el proceso. Por otra parte, también compartimos las palabras de Feijoo Sánchez, B. cuando reprochaba a la reforma el hecho de que no hubiese venido acompañada de un correcto desarrollo reglamentario respecto a la ejecución de algunas de las penas que podría imponerse a las personas jurídicas, como la intervención judicial del art. 33.7 g) CP, ausencia que dificultará o incluso impedirá su posible aplicación, en "La responsabilidad penal de las personas jurídicas..." ant. cit., p. 125.

${ }^{78}$ Rodríguez Ramos, L. Op. cit. ant.

${ }^{79}$ En esta línea Heine, G. quien considera que no resulta recomendable un deber empresarial de responsabilizarse en general y, pese a partir inicialmente de que dicha responsabilidad debería limitarse a los riesgos medioambientales y los derivados de los procesos tecnológicos, admite que se debería extender también a delitos graves económicos y tributarios, sobre todo, respecto a aquéllos a los que el Derecho penal individual no ha podido dar una adecuada y satisfactoria respuesta. En "Modelos de responsabilidad jurídico-penal..." cit. ant., p. 63.
} 
que parece que su utilización no sólo resultaría mucho más legítima, sino que además, podría jugar un importante papel preventivo. ${ }^{80}$

Tampoco nos parece adecuado que el sistema creado haya hecho depender la responsabilidad de las personas jurídicas siempre y en todo caso de la constatación de un hecho injusto realizado por una persona física, aunque no se le tenga que identificar, ya que este requisito impide que el sistema de responsabilidad colectiva español pueda aplicarse a aquellos casos, perfectamente imaginables, en los que los daños para bienes jurídicos que el Derecho penal debería intentar de evitar (p. ej. el vertido lesivo del medio-ambiente) no se hubiesen producido como consecuencia de una actuación individual, sino precisamente por la existencia del management colectivo defectuoso derivado de una acumulación de decisiones empresariales, individualmente permitidas, pero que al sumarse habrían llevado a su causación.

Otro aspecto que también resulta criticable, a nuestro juicio, es que el nuevo sistema sólo permita imputar responsabilidad penal a las personas jurídicas por los delitos que cometan las personas físicas que fuesen sus directivos o representantes o aquellas otras que estuviesen sometidas a la autoridad de estos últimos sujetos, olvidándose así de que pueden y de hecho existen muchas formas de agrupación de personas jurídicas que podrían ser utilizadas para limitar la eficacia represora y, por tanto, también la preventiva de este nuevo sistema aprovechándose de tal restricción.

Así, por ejemplo, bastaría con crear una pequeña sociedad dotada de poco capital y administrada directamente por su matriz (una filial), a la que se le atribuirían todas las actividades peligrosas que se quisiesen realizar, para estar seguro de que si alguna de ellas llegase a generar un delito, éste nunca podría determinar la responsabilidad penal de quienes realmente ampararon o incluso fomentaron su realización, los dominadores de la referida matriz, al quedar dicha sociedad y sus integrantes, conforme a lo establecido en el art. 31 bis CP, al margen de cualquier posible responsabilidad penal que se pudiese derivar del delito producido.

Entendemos, en tal sentido, que el sistema nace ya con un grave problema, como es el de partir de una concepción puramente formal de las empresas que se sustenta exclusivamente en el criterio de la personalidad jurídica.

\footnotetext{
80 También cuestionan la elección de delitos realizada por el legislador Muñoz Conde, F. / García Arán, M., op. cit. ant., p. 629; Gómez Martín, V., op. cit. ant., p. 130; Zugaldía Espinar, J. M., en Fundamentos de Derecho penal... cit. ant., pp. 590 y 591; Gómez-Jara Díez, C., "La responsabilidad penal de las personas jurídicas en la reforma..." cit. ant.; Solé Ramón, A., "La responsabilidad penal de las personas jurídicas. Hacia una nueva regulación de la persona jurídica como sujeto activo del Derecho penal y procesal penal", en RGDP 13 (2010), www. Iustel.com (últ. Vis. 10-52011), p. 23, entre otros.
} 
Galán - La responsabilidad penal de la persona jurídica...

Mucho más adecuado habría sido, a nuestro juicio, que se mantuviese una concepción material y sustantiva de la empresa fundamentada en su carácter de conjunto de recursos materiales y personales que se dirigen coordinadamente a la realización de una actividad económica; concepción que seguiría la estela de lo ya sostenido por el TEJ con respecto a la imputación de responsabilidad administrativa a tales entidades, ${ }^{81}$ se correspondería con el fundamento material que, a nuestro juicio, sustenta su sistema de responsabilidad (empresa como fuente de peligros)y que además permitiría solucionar el problema que le plantean las agrupaciones de empresas dotadas de varias y diferentes personalidades jurídicas.

De hecho, esta concepción parece haber encontrado ya un cierto reflejo en algunas de las prescripciones que configuran el comentado sistema, como la contemplada en el art. 130.2 CP que permite transferir la responsabilidad penal de la persona jurídica inicialmente condenada, tras su disolución aparente, precisamente, a aquella o aquellas otras que heredasen sus recursos materiales y personales, ${ }^{82}$ lo que demostraría que el mantenimiento de la concepción material y no meramente formal de la empresa aquí propuesto no vendría sino a continuar el camino que dicho precepto ya habría iniciado.

Finalmente, no podemos dejar de destacar el hecho de que el nuevo sistema de responsabilidad del art. 31 bis CP haya venido a oscurecer aún más la ya de por sí controvertida aplicación y naturaleza de las denominadas consecuencias accesorias, contempladas en el art. 129 CP.

Antes de la Ley Orgánica 5/2010 estas consecuencias eran tenidas por algunos como verdaderas penas. ${ }^{83}$ Otros las concebían como medidas de

\footnotetext{
81 Sobre este tema, véase lo comentado por Heine, G. quien, partiendo de lo dispuesto por el Tratado de la Unión Europea y de la interpretación que del mismo ha hecho el TEJ propone extender la responsabilidad penal más allá de los entes colectivos dotados de personalidad jurídica, llevándola hacia la empresa definida desde una óptica económica, mucho más amplia que aquella que se vincula y refiere al mero dato de su personalidad jurídica. En "Modelos de responsabilidad jurídico-penal..." cit. ant., pp. 56 y 57. En nuestra doctrina, también se han mostrado partidarios de esta concepción material y económica de la empresa, superadora de su definición formal meramente vinculada a su personalidad jurídica; Gómez-Jara Díez, C., "La responsabilidad penal de las personas jurídicas en la reforma...” cit. ant.; y BACIGALUPO, S., op. cit. ant. Sobre el concepto de empresa mantenido por el Tribunal de Justicia de las Comunidades Europeas y sus características, véase, por todos, lo apuntado por Tiedemann, K., Manual de Derecho penal económico. Parte Generaly Especial. Ed. Tirant lo Blanch, Valencia, 2010, pp. 193 y 194.

82 También considera que este precepto mantiene una concepción económica y no meramente formal de la persona jurídica, Feijoo Sánchez, B. en "La responsabilidad penal de las personas jurídicas..." ant. cit., p. 137.

83 Así, por ejemplo, lo entendía Zugaldía Espinar, J. M., "La responsabilidad criminal de las personas jurídicas en el derecho penal español. (Requisitos sustantivos y procesales para la imposición de las penas previstas en el art. 129 del Código Penal)", en El nuevo Derecho penal español. Estudios penales en memoria al profesor José Manuel V alle Muñi, Ed. Aranzadi, Navarra, 1991, p. 895.
} 
seguridad, ${ }^{84}$ mientras que no faltaban voces que las consideraban como consecuencias del delito de naturaleza diferente al resto de las que se contemplaban en nuestro ordenamiento penal. ${ }^{85}$

La reforma podría haber servido para solucionar por fin tan controvertido tema. Sin embargo, solo ha venido a enturbiarlo aún más.

La nueva redacción del art. $129 \mathrm{CP}$ permite imponer muchas de las medidas que el art. 33.7 de nuestro CP contempla como penas aplicables a las personas jurídicas a toda empresa, organización, grupo, entidad o agrupación de personas que no esté comprendida en el ámbito de aplicación del art. 31 bis CP precisamente por carecer de personalidad jurídica.

Para unos esta declaración supone la ratificación definitiva de la naturaleza de verdaderas penas de tales medidas, ya que si son penas cuando se aplican a una persona jurídica, no parece que puedan dejar de serlo y pierdan dicha naturaleza por el mero hecho de que se apliquen a otra entidad colectiva no dotada de personalidad jurídica. ${ }^{86}$

Sin embargo, y a nuestro modo de ver, este último planteamiento no resulta sostenible, ya que, si bien es cierto que las medidas impuestas conforme a lo establecido por el art. $129 \mathrm{CP}$ son materialmente idénticas a las que se imponen conforme al comentado art. 31 bis $\mathrm{CP}$, existen importantes diferencias en sus respectivos sistemas de aplicación que demuestran que ambas posibles consecuencias jurídicas del delito gozan de una naturaleza bien diferente.

Así, por ejemplo, no parece que respalden la naturaleza de verdaderas penas de las consecuencias accesorias del art. $129 \mathrm{CP}$ el hecho de que su imposición sea facultativa para los jueces, ni que su imposición no esté vinculada por ningún sistema reglado de graduación, ni que el legislador haya eliminado cualquier clase de referencia a criterios de imputación que puedan servir para fundamentar el juicio de reproche que respaldaría su calificación de penas.

\footnotetext{
${ }^{84}$ Como medidas de seguridad las calificaba Silva Sánchez, J. M. "La responsabilidad penal de las personas jurídicas...", pp. 247 y 248.

${ }^{85}$ En este sentido véase lo comentado en su día, por ejemplo, por Mir Puig, S. "Una tercerea vía en materia de responsabilidad penal de las personas jurídicas", cit. ant.

${ }^{86}$ Así lo mantiene, por ejemplo, Rodríguez Ramos, L., op. cit. ant.; Bacigalupo, S., op. cit. ant. Frente a este planteamiento, sin embargo, destaca Feijoo Sánchez, B. que al hablarse en su nueva redacción específicamente de "consecuencias accesorias a la pena que corresponda al autor del delito" se dejaría claro que dichas consecuencias serían diferentes de las verdaderas penas aplicables a las personas jurídicas. En "La reforma del art. 129 CP", en Estudios sobre las reformas del Código Penal operadas por las LO 5/2010de 22 de junio y 3/2011 de 28 de enero, Ed. Civitas, Cizur Menor, Navarra, 2011, p. 247.
} 
Galán - La responsabilidad penal de la persona jurídica...

Más bien parece que el legislador considere a las agrupaciones no dotadas de personalidad jurídica como entidades carentes de capacidad para recibir reproche penal alguno, pero que pueden ser utilizadas como medios para cometer o facilitar la comisión de delitos, lo que las convierte en instrumentos peligrosos que han de ser neutralizados mediante la imposición de medidas exclusivamente inocuizadoras y que, consecuentemente, no conllevarán el reproche que dota de significado y fundamento a las verdaderas penas.

Tal vez en el futuro y una vez que se dé el salto del sistema de responsabilidad penal de las personas jurídicas a un verdadero sistema global de responsabilidad penal colectiva, como el que se ha propuesto en este trabajo, se consiga terminar con la existencia de esta suerte de sistema dual de tratamiento penal de las entidades colectivas, pero lo cierto y verdad es que, a día de hoy y a pesar de los importantes avances introducidos por la LO 5/2010, no podemos sino reconocer que todavía nos queda mucho camino por andar hasta alcanzar un Derecho penal que verdaderamente responda de forma coordinada y adecuada a todos los retos que la existencia de agrupaciones y organizaciones colectivas de personas plantea a nuestra sociedad. 
REJ - Revista de Estudios de la Justicia - No 15 - Año 2011

\section{BIBLIOGRAFÍA}

* AlONSO GALlO, Jaime: "Los programas de cumplimiento", en Estudios sobre las reformas del Código Penal operadas por las LO 5/2010de 22 de junio y 3/2011 de 28 de enero. Ed. Civitas. Cizur Menor (Navarra), 2011.

* BACIGALUPO, Silvina: "Los criterios de imputación de la responsabilidad penal de los entes colectivos y de sus órganos de gobierno (art. 31 bis y 129 CP) (1)" en La Ley No 7541, 201, en www.laley.es (últ. vis. 10-7-2011).

* Bajo FERnÁndeZ, Miguel / BACIGALUPO SAGGESE, Silvina, Derecho penal económico. Ed. Ramón Areces. Madrid, 2010.

* BECK, Ulrich: ¿Qué es la globalización? Ed. Paidos. Barcelona, 2008.

* CARBOnell mateu, Juan Carlos/MORALES PRATS, Fermín: "Responsabilidad penal de las personas jurídicas", en Comentarios a la reforma penal de 2010. Ed. Tirant lo Blanch. Valencia, 2010.

* DOLZ LAGO, Manuel Jesús: "Sobre el estatuto penal de la persona jurídica como sujeto responsable. A propósito sobre la circular de la fiscalía general del Estado 1/2011. La Ley $\mathrm{N}^{\circ}$ 7665", 2011, en www.laley.es (últ. vis. 10-7-2011).

* FEIJOO SÁNCHEZ, Bernardo: “La responsabilidad penal de las personas jurídicas", en Estudios sobre las reformas del Código Penal operadas por las LO 5/2010de 22 de junio y 3/2011 de 28 de enero. Ed. Civitas. Cizur Menor (Navarra), 2011.

"La reforma del art. 129 CP", en Estudios sobre las reformas del Código Penal operadas por las LO 5/2010de 22 de junio y 3/2011 de 28 de enero. Ed. Civitas. Cizur Menor (Navarra), 2011.

* GALÁN MUÑOZ, Alfonso: “¿Societas delinquiere nec puniere potest? Algunas consideraciones críticas sobre el artículo 31.2 CP”, en RDPC No 18 (2006).

* GARCÍA ARÁN, Mercedes: "Algunas Consideraciones sobre la responsabilidad penal de las personas jurídicas”, en El nuevo Código Penal: presupuestos y fundamentos, libro bomenaje al profesor Doctor Don Ángel Torio López. Ed. Comares. Granada, 1999.

* GRACIA MARTíN, Luis: "La cuestión de la responsabilidad penal de las propias personas jurídicas" en Dogmática penal, política criminal y criminología en evolución. Ed. Comares. Universidad de La Laguna, 1997.

* GÓMEZ-jARA DÍEZ, Carlos: La culpabilidad penal de la empresa. Ed. Marcial Pons. Madrid, 2005.

“Autoorganización empresarial y autorresponsabilidad empresarial” en RECPC 08-05 (2006), en http://criminet.ugr.es/recpc/08/recpc08-05.pdf (últ. vis. 2-7-2011).

"El modelo constructivista de autorresponsabilidad penal empresarial", en Modelos de autorresponsabilidad penal empresarial. Propuestas globales contemporáneas. Ed. Aranzadi. Cizur Menor (Navarra), 2006.

"El nuevo artículo 31.2 del Código Penal: cuestiones de lege lata y de lege ferenda", en Modelos de autorresponsabilidad penal empresarial. Propuestas globales contemporáneas. Ed. Aranzadi. Cizur Menor (Navarra), 2006.

"La responsabilidad penal de las personas jurídicas en la reforma del Código Penal". La Ley $\mathrm{N}^{\mathrm{o}}$ 7534, 2010, en www.laley.es (últ. vis. 1-5-2011).

* GÓmeZ MARTín, Víctor: Comentarios al Código Penal. Reforma LO 5/2010. Ed. Tirant lo Blanch. Valencia, 2011.

* gómez Rivero, Carmen/ MARTínez GONZÁlEZ, María Isabel/ NúÑEZ CASTAÑO, Elena: "Crónica de Derecho Penal 2009", en Crónica Jurídica Hispalense, Revista de la Facultad de Derecho No 8/2010.

* GÓMEZ TOMILLO, Manuel: Introducción a la responsabilidad penal de las personas jurídicas en el sistema español. Ed. Lex Nova. 2010.

* gOnZÁlez-CuÉllar SERrANO, Nicolás/ JUANES PECES, Ángel: “La responsabilidad penal de las personas jurídicas y su enjuiciamiento en la reforma de 2010. 
Galán - La responsabilidad penal de la persona jurídica...

Medidas a adoptar antes de su entrada en vigor", en La Ley $\mathrm{N}^{\circ} 7541$, 201, en www.laley.es (últ. vis. 10-7-2011).

* HEINE, Günter: Die strafrechtliche Verantwortlichkeit von Unternehemen, Von individuallen Feblverbalten ₹и kollektiven Feblenwircklungen inbesodnere bei Grossrisiken. Ed. Nomos. Baden Baden, 1995.

"Modelos de responsabilidad jurídico-penal originaria de la empresa", en Modelos de autorresponsabilidad penal empresarial. Propuestas globales contemporáneas. Ed. Aranzadi. Cizur Menor (Navarra), 2006.

* LÓPEZ PEREgRíN, Carmen: "La discusión sobre la responsabilidad penal de las personas jurídicas y las consecuencias accesorias del art. 129 CP, once años después" en Problemas actuales del Derecho penal y de la criminología. Estudios penales en memoria de la profesora Dra. María del Mar Díaz Pita. Ed. Tirant lo Blanch. Valencia, 2008.

* Martínez-BUján PÉREZ, Carlos: Derecho penal económico. Parte General. Ed. Tirant Lo Blanch. Valencia, 1999.

* MATA BARRANCO, Norberto: "La responsabilidad penal de las personas jurídicas", en Reforma del Código Penal. Perspectiva económica tras la entrada en vigor de la Ley Orgánica 5/2010 de 22 de junio. Situación jurídico-penal del Empresario. Ed. El Derecho. Madrid, 2010.

* MIR PUIG, Santiago: Derecho Penal. Parte General. Ed. Reppertor. Barcelona, 2005.

"Una tercera vía en materia de responsabilidad penal de las personas jurídicas, en RECPC 06-01 (2004) en http:// criminet.ugr.es/recpc/06/recpc06-01.pdf (últ. vis. 12-7-2011).

* MUÑoz CONDE, Francisco/ GARCÍA ARÁN, M.: Derecho Penal. Parte General. Ed. Tirant lo Blanch, Valencia, 2010.

* NIETO MARTÍN, Adán: La responsabilidad penal de las personas jurídicas: Un modelo lesgislativo. Ed. Iustel. Madrid, 2008.

* NÚÑEZ CASTAÑO, Elena: Responsabilidad penal en la empresa. Ed. Tirant lo Blanch. Valencia, 2000.

* ORTS BERENGUER, Enrique / GONZÁLEZ CUSSAC, José Luis: Compendio de Derecho penal. Parte General. Ed. Tirant lo Blanch. Valencia, 2010.

* Quintero OLIVARES, Gonzalo: "Personas jurídicas, entes, grupos, y sus individuos. Su responsabilidad penal tras la reforma de la Ley Orgánica 5/2010” en El Cronista del Estado Social y Democrático de Derecho No 22, 2011.

* ROBLES PLANAS, Ricardo: “¿Delitos de personas jurídicas?”. En Indret, 344, en http://www.indret.com/pdf/344. pdf (últ. vis. 12-3-2011).

* RODRÍGUEZ RAMOS, Luis: “¿Cómo puede delinquir una persona jurídica en un sistema penal antropocéntrico? (La participación en el delito de otro por omisión imprudente: pautas para su prevención)." La Ley No 7561 2011, en www.laley.es (últ. vis. 8-6-2011).

* SÁNCHEZ REYERO, David Gerardo: "Estudio sobre la responsabilidad de la persona jurídica, el doloso dependiente y el corporate compliance", La Ley $\mathrm{N}^{\circ} 7663$, 2011, en www.laley.es (últ. vis. 10-7-2011).

* SCHÜNEMANN, Benard: Unternehmenskriminalität und Strafrecht- Eine Untersuchung der Verantwortlichkeit der Unternehmen und ibre Führungskräfte nach geldentem und replanten Straf- und Ordnungswiedrigkeitenrecht, Ed. Heymnann. Köln, 1979.

"Strafdogmatische und Kriminalpolitische Grundfragen der Unternehmenskriminalität". Wistra 2, 1982, traducido y publicado en español bajo el título "Cuestiones básicas de dogmática jurídico-penal y de política criminal acerca de la criminalidad de empresa" en ADPCP T. 41, 1988.

"La punilidad de las personas jurídicas desde la perspectiva europea" en Hacia un Derecho penal económico europeo. Ed. BOE. Madrid, 1995.

"Responsabilidad penal en el marco de la empresa. Dificultades relativas a la individualización de la imputación” en ADPCP, Vol. LV, 2002. 
REJ - Revista de Estudios de la Justicia - No 15 - Año 2011

"La responsabilidad penal de las empresas y sus órganos directivos en la Unión Europea" en Constitución europea y Derecho penal económico. Mesas redondas Derecho y economía. Ed. Ramón Areces. Madrid, 2006.

* SILVA SÁNCHEZ, Jesús María: "La responsabilidad penal de la persona jurídica y las consecuencias accesorias del art. 129 del Código Penal" En Derecho penal económico. Manuales de formación continuada, 14. Madrid, 2001.

"La reforma del Código Penal: Una aproximación desde el contexto", en La Ley $\mathrm{N}^{\circ}$ 7465, 201, en www.laley.es (últ. vis. 10-7-2011).

* SOLÉ RAMÓN, Anna: "La responsabilidad penal de las personas jurídicas. Hacia una nueva regulación de la persona jurídica como sujeto activo del Derecho penal y procesal penal", en RGDP 13 (2010), www. Iustel.com (últ. vis. 10-5-2011).

* TIEDEMANN, Klaus: "Die "Bebussung" von Unternehmen nach dem z. Gesetz zur Bekämpfung der Wirtschaftskriminalität", NJW Heft 19, 1998.

2010.

Manual de Derecho penal económico. Parte General y Especial. Ed. Tirant lo Blanch. Valencia,

* VOGEL, Joachim: "Estado y tendencias de la armonización del Derecho penal material en la Unión Europea". RP No 10, 2002.

* ZUGALDÍA ESPINAR, José Miguel: "La responsabilidad criminal de las personas jurídicas en el derecho penal español. (Requisitos sustantivos y procesales para la imposición de las penas previstas en el art. 129 del Código penal)", en El nuevo Derecho penal español. Estudios penales en memoria al profesor José Manuel V alle Muñiz. Ed. Aranzadi. Navarra, 1991.

Fundamentos de Derecho penal. Parte General. Ed. Tirant lo Blanch. Valencia, 2010.

"Societas delinquere potest (Análisis de la reforma operada en el Código Penal español por la LO 5/2010, de 22 de junio)", en La Ley Penal No 76, 2010, en www.laley.es (últ. vis. 107-2011).

* ZÚNIGA RODRÍGUEZ, Laura: Bases para un modelo de imputación de responsabilidad penal a las personas jurídicas. Ed. Aranzadi. Cizur Meno (Navarra), 2009.

"Responsabilidad penal de las personas jurídicas y criminalidad organizada", en Un Derecho penal comprometido. Libro homenaje al Prof. Dr. Gerardo Landrove Diaz. Ed. Tirant lo Blanch. Valencia, 2011. 